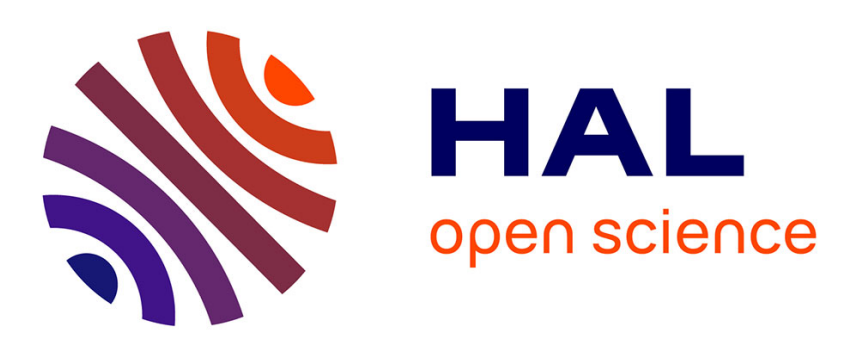

\title{
Genistein and daidzein prevent low potassium-dependent apoptosis of cerebellar granule cells
}

\author{
Anna Atlante, Antonella Bobba, Gianluca Paventi, Roberto Pizzuto, \\ Salvatore Passarella
}

\section{- To cite this version:}

Anna Atlante, Antonella Bobba, Gianluca Paventi, Roberto Pizzuto, Salvatore Passarella. Genistein and daidzein prevent low potassium-dependent apoptosis of cerebellar granule cells. Biochemical Pharmacology, 2009, 79 (5), pp.758. 10.1016/j.bcp.2009.10.005 . hal-00547636

\section{HAL Id: hal-00547636 \\ https://hal.science/hal-00547636}

Submitted on 17 Dec 2010

HAL is a multi-disciplinary open access archive for the deposit and dissemination of scientific research documents, whether they are published or not. The documents may come from teaching and research institutions in France or abroad, or from public or private research centers.
L'archive ouverte pluridisciplinaire HAL, est destinée au dépôt et à la diffusion de documents scientifiques de niveau recherche, publiés ou non, émanant des établissements d'enseignement et de recherche français ou étrangers, des laboratoires publics ou privés. 


\section{Accepted Manuscript}

Title: Genistein and daidzein prevent low potassium-dependent apoptosis of cerebellar granule cells

Authors: Anna Atlante, Antonella Bobba, Gianluca Paventi, Roberto Pizzuto, Salvatore Passarella

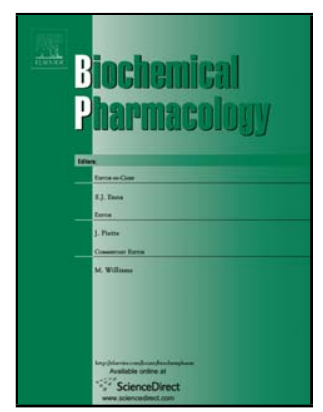

PII:

S0006-2952(09)00899-5

DOI: doi:10.1016/j.bcp.2009.10.005

Reference: BCP 10351

To appear in: $B C P$

Received date: 25-7-2009

Revised date: 29-9-2009

Accepted date: 6-10-2009

Please cite this article as: Atlante A, Bobba A, Paventi G, Pizzuto R, Passarella $\mathrm{S}$, Genistein and daidzein prevent low potassium-dependent apoptosis of cerebellar granule cells, Biochemical Pharmacology (2008), doi:10.1016/j.bcp.2009.10.005

This is a PDF file of an unedited manuscript that has been accepted for publication. As a service to our customers we are providing this early version of the manuscript. The manuscript will undergo copyediting, typesetting, and review of the resulting proof before it is published in its final form. Please note that during the production process errors may be discovered which could affect the content, and all legal disclaimers that apply to the journal pertain. 


\section{GENISTEIN AND DAIDZEIN PREVENT LOW POTASSIUM-DEPENDENT APOPTOSIS OF CEREBELLAR GRANULE CELLS}

Anna Atlante ${ }^{1}$, Antonella Bobba ${ }^{1}$, Gianluca Paventi ${ }^{2}$, Roberto Pizzuto ${ }^{3}$ and Salvatore Passarella ${ }^{3}$

${ }^{1}$ Istituto di Biomembrane e Bioenergetica, CNR, Via G. Amendola 165/A, 70126 Bari; ${ }^{2}$ Dipartimento di Scienze Animali, Vegetali e dell'Ambiente, Università del Molise, via De Sanctis 86100 Campobasso; ${ }^{3}$ Dipartimento di Scienze per la Salute, Università del Molise, via De Sanctis 86100 Campobasso, Italy

\section{Corresponding author:}

Salvatore Passarella

Dipartimento di Scienze per la Salute - Università del Molise - Campobasso, Italy

TEL +39 (0874) 404243; +39 (080) 5443364

FAX $+39(080) 5443317$

E-mail: passarel@unimol.it, a.atlante@ibbe.cnr.it

Abbreviations: Act D, actinomycin D; ANT, adenine nucleotide translocator; Ap5A, $\mathrm{P}_{1}, \mathrm{P}_{5^{-}}$ Di(adenosine-5')penta-phosphate; ASC, ascorbate; ATP D.S., ATP detecting system; ATR, atractyloside; BME, basal medium Eagle; CE, catechin; CGC, cerebellar granule cell; $\mathbf{C N}^{-}$, potassium cyanide; CsA, cyclosporine A; Cyt $c$, cytochrome $c$; DIV, days in vitro; DMSO, dimethyl sulfoxide; DZN, daidzein; DZN-S-K5 cells, S-K5 cells treated with daidzein; EC, epicatechin; $\mathbf{F e}^{3+}$-cyt $\boldsymbol{c}$, ferricytochrome $c$; $\mathbf{F e}^{2+}$-cyt $c$, ferrocytochrome $c$; GEN, genistein; GEN-SK5 cells, S-K5 cells treated with genistein; G6PD; glucose-6-phosphate dehydrogenase; MIM, mitochondrial inner membrane; MOM, mitochondrial outer membrane; mPT, mitochondrial permeability transition; mPTP, mitochondrial permeability transition pore; PTE, pterine; RCR, respiratory control ratio; S.D., standard deviation; S-K25 cells, control cells; S-K5 cells, apoptotic cells; $x$ h S-K5 cells, apoptotic cells $x$ h after the induction of apoptosis; SOD, superoxide dismutase; SUCC, succinate; XO, xanthine oxidase. 


\begin{abstract}
We have investigated the ability of certain dietary flavonoids, known to exert beneficial effects on the central nervous system, to affect neuronal apoptosis. We used cerebellar granule cells undergoing apoptosis due to potassium deprivation in a serum-free medium in either the absence or presence of the flavonoids genistein and daidzein, which are present in soy, and of catechin and epicatechin, which are present in cocoa. These compounds were used in a blood dietary concentration range. We found that genistein and daidzein, but not catechin and epicatechin, prevented apoptosis, with cell survival measured $24 \mathrm{~h}$ after the induction of apoptosis being higher than that of the same cells incubated in flavonoid free medium ( 80 and 40\%, respectively); there was no effect in control cells. A detailed investigation of the effect of these compounds on certain mitochondrial events that occur in cells en route to apoptosis showed that genistein and daidzein prevented the impairment of glucose oxidation and mitochondrial coupling, reduced cytochrome $\mathrm{c}$ release, and prevented both impairment of the adenine nucleotide translocator and opening of the mitochondrial permeability transition pore. Interestingly, genistein and daidzein were found to reduce the levels of reactive oxygen species, which are elevated in cerebellar granule cell apoptosis. These findings strongly suggest that the prevention of apoptosis depends mainly on the antioxidant properties of genistein and daidzein. This could lead to the development of a flavonoid-based therapy in neuropathies.
\end{abstract}

Key Words: genistein, daidzein, apoptosis, cerebellar granule cells, antioxidant, mitochondria. 


\section{Introduction}

Deregulated apoptotic mechanisms have been implicated in many pathologic conditions, including AIDS, infectious diseases, inflammation, cancer, heart failure, osteoporosis, stroke and trauma. In particular, the process is involved in many human neurological disorders, including Alzheimer's, Parkinson's and Huntington's diseases and amyotrophic lateral sclerosis [1]. It is intriguing that key events/components in the cellular regulation of apoptosis have been identified and thus may be targeted by therapeutic strategies [2]. In this regard, targeting apoptosis with dietary bioactive agents could be a therapeutic approach to either prevent apoptosis in those diseases that have an apoptotic origin [3] or induce apoptosis, for instance in cancer cells. To better investigate whether and how some dietary compounds can affect apoptosis, the availability of an experimental system is needed in which a dissection of the steps that lead to cell death has already been done.

We have already shown how apoptosis of cerebellar granule cells (CGCs) occurs when they are deprived of extracellular $\mathrm{K}^{+}$(SK5 cells) [for ref, see 4-9]. In particular, we investigated the role of mitochondria in this process. Briefly, in early apoptosis (0-3h after induction) the rate of glucose oxidation by CGCs decreases [5], mitochondria are subjected to time-dependent uncoupling [5] and elevated production of reactive oxygen species (ROS) occurs [6]. Cytochrome $c$ (cyt $c$ ) is released from the mitochondria while still coupled $[6,7]$ and an increase in the ATP level occurs [8]. In late apoptosis (3-8 $\mathrm{h}$ after induction), an alteration of the adenine nucleotide translocator (ANT) occurs, with ANT becoming a component of the mitochondrial permeability transition pore (mPTP); the latter is dispensable for occurrence of apoptosis [9]. On the assumption that neuropathies are a result of neuronal apoptosis, the identification of compounds able to protect neurons against apoptosis is highly desirable. 
Given that the soy flavonoids have been claimed to improve human memory and neuro-cognitive performance, there is reason to suspect that this might be due to their ability to protect neurons against stress-induced injury, perhaps preventing apoptosis [10, 11]. However, although the biological processes modulated by flavonoids, and especially by the isoflavone genistein (GEN), have been extensively studied, there is no clear understanding of the cellular and molecular mechanisms of action involved [12]. Flavonoids may target mitochondria in apoptosis, given that they have been reported to impair mitochondrial ATPase [13], to modulate the mPTP [14, 15] and interact with other mitochondria-associated pro-apoptotic factors such as DIABLO/smac [16, 17].

On the other hand, in recent reviews GEN was shown to have a variety of effects, including binding to estrogen receptors, antioxidative activity, the capacity to increase cellular reduced glutathione and effects on other physiological functions [for refs, see 18]. In particular, GEN was reported to be a potent inhibitor of tyrosine kinase (TK, E.C.2.7.10) in tumor tissues [19, 20] and of xanthine oxidase (XO, E.C.1.2.3.2) [21]. Recently, protection by GEN of the rat brain synaptosome and cultured hippocampal neurons from insult induced by $\beta$-Amyloid peptide A $\beta 25-35$ (for refs see 18) was found. Indeed, GEN was shown to be either pro-apoptotic or anti-apoptotic depending both on its concentration and the cell system [14, 22-24]. Similarly, the GEN analogue daidzein (DZN), which does not inhibit TK [25], can inhibit D-gal-induced apoptosis via the Bcl-2/Bax apoptotic pathway [26] and may be a potential medical candidate for neurodegeneration therapy. DZN exhibits an antioxidant activity [27] and shows other biological properties, including estrogen-like and estrogenin-dependent effects [for refs see 28].

Herein we report investigations on the effect of GEN and DZN on the steps outlined above in the process by which CGCs undergo apoptosis as a result of potassium deprivation. We found that GEN and DZN, the latter with a lower efficiency, when used in the "dietary concentration range" (up to 
$10 \mu \mathrm{M}$ ) [for refs see 29-31], can prevent apoptosis from occurring in a manner consistent with their antioxidant activity. This provides them with a role as potential drugs in neurodegenerative disease therapy. In contrast with [32, 33], we found that GEN does not impair xanthine oxidase, at least in CGCs.

\section{Materials and Methods}

2.1 Reagents. Tissue culture medium and fetal calf serum were purchased from GIBCO (Grand Island, NY) and tissue culture dishes were from NUNC (Taastrup, Denmark). All enzymes and biochemicals were from Sigma Chemicals Co. (St. Louis, MO, USA).

All procedures involving the use of animals were performed in compliance with relevant laws and institutional guidelines. The animals were anesthetized and insensitive to pain throughout the procedure.

2.2 Cell cultures. Primary cultures of CGCs were obtained from dissociated cerebella of 7-day-old Wistar rats as in Levi et al. [34]. Cells were plated in basal medium Eagle (BME) supplemented with $10 \%$ fetal calf serum, $25 \mathrm{mM} \mathrm{KCl,} 2 \mathrm{mM}$ glutamine and $100 \mu \mathrm{g} / \mathrm{ml}$ gentamicin on dishes coated with poly-L-Lysine. Cells were plated at $2 \times 10^{6}$ per $35 \mathrm{~mm}$ dish, $6 \times 10^{6}$ per $60 \mathrm{~mm}$ dish, or $15 \times 10^{6}$ per $90 \mathrm{~mm}$ dish. Arabinofuranosylcytosine $(10 \mu \mathrm{M})$ was added to the culture medium $18-22$ hr after plating to prevent proliferation of non-neuronal cells.

2.3 Induction of apoptosis. Primary neuronal cultures at 6-7 days in vitro (DIV), which showed typical neuronal morphologies with healthy cell bodies and intact processes, were used for the experiments. Apoptosis was induced as in D'Mello et al. [35]: cells were washed twice and switched to serum-free BME (S-) containing $5 \mathrm{mM} \mathrm{KCl}$ supplemented with $2 \mathrm{mM}$ glutamine and $100 \mu \mathrm{g} / \mathrm{ml}$ gentamicin. In some experiments, a variety of compounds (including the flavonoids) were also 
added at the induction time at the indicated concentrations selected to avoid any possible interference with cell viability. The flavonoids were dissolved in dimethyl sulfoxide (DMSO) and stored at $-20^{\circ} \mathrm{C}$ in the dark, with the final DMSO concentration kept below $0.1 \%$. The drug exposure was terminated by removing the flavonoid-containing media, followed by washing twice and replacing with fresh media. Sister cultures prepared under the same conditions were used in each experiment. Control cells (without or with DMSO) were treated identically but maintained in serumfree BME medium supplemented with $25 \mathrm{mM} \mathrm{KCl}$ for the indicated times; they are referred to as $\mathbf{S}$ $\mathbf{K} 25$ cells. Apoptotic cells are referred to as $\mathbf{S}-\mathbf{K 5}$ cells, and to indicate the different times $\mathbf{x}$ after apoptosis induction, they are referred to as xtime-S-K5.

The occurrence of apoptosis was checked, as in $[6,35]$, by measuring DNA laddering and prevention of death due to the addition of Actinomycin D (Act D). The occurrence of necrosis was assessed, as in [6], by checking the release of L-lactate dehydrogenase and the ability of MK801 to prevent CGC death.

2.4 Assessment of CGC survival. As advised in [36, 37], cell survival was quantified by counting the number of intact nuclei using a hemacytometer after lysing the cells in detergent-containing solution as in $[38,39]$. Each measurement was performed in triplicate and reported as the mean \pm SEM. The data are expressed as the percentage of intact nuclei in the control cultures at each time point.

2.5 DNA fragmentation analysis. Fragmentation of DNA was performed as in [6, 40]. Briefly, CGCs $\left(6 \times 10^{6}\right)$ were plated in poly L-lysine-coated $60 \mathrm{~mm}$ tissue culture dishes, collected with cold phosphate-buffered saline (PBS, $\mathrm{pH}$ 7.2) and, after removal of the medium and washing once with cold PBS, the cells were centrifuged at $3500 \mathrm{~g}$ for $5 \mathrm{~min}$. The pellet was lysed in $10 \mathrm{mM}$ Tris- $\mathrm{HCl}$, $10 \mathrm{mM}$ EDTA, and $0.2 \%$ Triton X-100 (pH 7.5). After $30 \mathrm{~min}$ on ice, the lysates were centrifuged at $17000 \mathrm{~g}$ for $10 \mathrm{~min}$ at $4^{\circ} \mathrm{C}$. The supernatant was digested with proteinase $\mathrm{K}$ and then extracted twice 
with phenol-chloroform/isoamyl alcohol (24:1). The aqueous phase, containing soluble DNA, was recovered and nucleic acids were precipitated with sodium acetate and ethanol overnight. The pellet was washed with 70\% ethanol, air-dried and dissolved in TE buffer (10 mM Tris-HCl, $1 \mathrm{mM}$ EDTA, $\mathrm{pH} 7.5)$. After digestion with RNase $\mathrm{A}\left(50 \mathrm{ng} / \mathrm{mL}\right.$ at $37^{\circ} \mathrm{C}$ for $\left.30 \mathrm{~min}\right)$, the sample was subjected to electrophoresis in a 1.8\% agarose gel and visualized by ethidium bromide staining. Soluble DNA from equal numbers of cells was loaded in each lane.

2.6 Cell suspension and homogenate preparations. Before each experiment, the culture medium was removed and the plated CGCs were washed with phosphate-buffered saline medium containing $138 \mathrm{mM} \mathrm{NaCl}, 2.7 \mathrm{mM} \mathrm{KCl}, 8 \mathrm{mM} \mathrm{Na}_{2} \mathrm{HPO}_{4}$, and $15 \mathrm{mM} \mathrm{KH}_{2} \mathrm{PO}_{4}$ at $\mathrm{pH} 7.4$ and then collected by gentle scraping into a volume of medium depending on the particular experiment.

2.6.1 Cell suspensions showed full viability, even though they lacked the morphological organization observed in culture dishes such as cell-cell and cell-substrate contacts, and had no neurites. Cell integrity, which remained essentially constant for 3-5 h, was quantitatively assessed by confirming the inability of cells to oxidize externally added succinate (SUCC), which cannot enter intact cells [41], and by confirming the ability of ouabain to block glucose transport into the cells [42]. The final cell suspension routinely contained $85-95 \%$ intact cells.

2.6.2 Cell homogenate from plated CGCs was obtained by washing them with PBS and collecting by gentle scraping to obtain a cell suspension that was then homogenized in a Dounce-Potter homogenizer using 10 strokes at $25^{\circ} \mathrm{C}$. The rupture of cell membranes was checked by confirming the failure of ouabain to inhibit glucose-dependent oxygen consumption [for refs, see 5].

The intactness of mitochondria in the cell homogenate was checked by measuring the activities of adenylate kinase (ADK, E.C.2.7.4.3) and glutamate dehydrogenase in the post-mitochondrial supernatant (GDH, E.C.1.4.1.3) [for refs see 5], which are marker enzymes of the mitochondrial 
intermembrane space and matrix, respectively. Mitochondrial coupling was monitored by measuring the respiratory control ratio (RCR), i.e., (oxygen uptake rate after ADP addition)/(oxygen uptake rate before ADP addition), with succinate used as a respiratory substrate.

\subsection{Polarographic measurements.}

2.7.1 Cellular and mitochondrial respiration. $\mathrm{O}_{2}$ consumption was measured polarographically using a Gilson 5/6 oxygraph with a Clark electrode, as in [5, 7]. Either intact cells or cell homogenates in PBS (about $1 \mathrm{mg}$ protein) were incubated in a thermostatted $\left(25^{\circ} \mathrm{C}\right)$ water-jacketed glass vessel (final volume $1.5 \mathrm{ml}$ ). The sensitivity of the instrument was set so as to allow rates of $\mathrm{O}_{2}$ uptake as low as 0.5 natom $\mathrm{min}^{-1} \mathrm{mg}^{-1}$ protein to be measured. Since the incubation chamber required continuous stirring to allow $\mathrm{O}_{2}$ to diffuse freely, the design included a magnetic stirring system. Oxygen uptake was initiated by adding either glucose or succinate to the cell suspension or homogenate, respectively.

Protein content was determined according to [43] with bovine serum albumin used as a standard.

2.7.2 Cytochrome c release. To detect the presence of active cyt $c$ in the extramitochondrial phase, the ability of cell homogenate to oxidize ascorbate (ASC) was checked [7]. Briefly, because ASC cannot permeate per se the outer mitochondrial membrane [for ref see 7], its oxidation must occur as a result of release from mitochondria of a component that can oxidize ASC and then reduce oxygen via cytochrome $c$ oxidase, i.e., cyt $c$. The rate of oxygen uptake was measured as the tangent to the initial part of the progress curve and expressed as natom $\mathrm{O} \mathrm{min} \mathrm{mg}^{-1}$ protein.

2.8 Superoxide anion detection in CGCs. Superoxide anion $\left(\mathrm{O}_{2}^{-{ }^{-}}\right)$was detected using the ferricytochrome $c\left(\mathrm{Fe}^{3+}\right.$-cyt $\left.c\right)$ method [44] as an increase in absorbance at $550\left(\varepsilon_{550 \mathrm{~nm}}=37 \mathrm{mM}^{-1} \mathrm{~cm}^{-}\right.$ ${ }^{1}$ at $25^{\circ} \mathrm{C}$ ) and was measured using a Perkin-Elmer LAMBDA-5 spectrophotometer equipped with a 
thermostatted holder. A calibration curve was made by using xanthine plus $\mathrm{XO}$ as an $\mathrm{O}_{2}{ }^{-\cdot}$ producing system, which produces ferrocytochrome $c\left(\mathrm{Fe}^{2+}\right.$-cyt $\left.c\right)$ in a 1:1 stoichiometry.

2.9 Xanthine oxidase assay. XO activity was assayed both by fluorimetric measurements (Perkin Elmer LS50; excitation and emission wavelengths of 345 and $390 \mathrm{~nm}$, respectively) of isoxantopterine formation from pterine as in [45], and by photometric measurements at $550 \mathrm{~nm}$ of XO-dependent $\mathrm{O}_{2}^{-\cdot}$ formation, as in [46].

2.10 Measurement of ATP levels. ATP levels in CGC extracts were determined by HPLC as in [8].

2.11 ANT measurement. Cell homogenate (0.1 mg protein) containing mitochondria was incubated at $25^{\circ} \mathrm{C}$ in $2 \mathrm{ml}$ of standard medium consisting of $200 \mathrm{mM}$ sucrose, $10 \mathrm{mM} \mathrm{KCl}, 1 \mathrm{mM} \mathrm{MgCl}$, and $20 \mathrm{mM}$ HEPES-Tris at $\mathrm{pH}$ 7.2. The appearance of ATP in the extramitochondrial phase, due to externally added ADP, was revealed as in [9] by using an ATP detecting system (ATP D.S.). This consisted of glucose (2.5 mM), hexokinase (HK, E.C.2.7.1.1, 0.5 e.u.), glucose-6-phosphate dehydrogenase (G6PD, E.C.1.1.1.49, 0.5 e.u.) and $\mathrm{NADP}^{+}(0.2 \mathrm{mM})$ in the presence of $\mathrm{P}_{1}, \mathrm{P}_{5^{-}}$ Di(adenosine-5')penta-phosphate (Ap5A), a specific inhibitor of adenylate kinase [for ref see 9]. The rate of $\mathrm{NADP}^{+}$reduction in the extramitochondrial phase was followed as an absorbance increase at $334 \mathrm{~nm}$, which was measured as the tangent to the initial part of the progress curve and expressed as nmol NADP ${ }^{+}$reduced/min x mg cell protein. Because the rate of ATP appearance measured in cell homogenates could depend on a number of events, including electron flow across the mitochondrial membrane, electrochemical proton gradient generation, ATP synthase and the adenine nucleotide content of the mitochondria, under each experimental condition, we investigated the rate-limiting step of the process leading to ATP efflux from the mitochondria as in [9].

\subsection{Measurement of the mitochondrial permeability transition pore opening.}


To monitor the onset of mPTP opening, cell homogenate was suspended in a medium containing $250 \mathrm{mM}$ sucrose, $2 \mathrm{mM}$ HEPES pH 7.4, $0.5 \mathrm{mM} \mathrm{K}_{2} \mathrm{HPO}_{4}, 1 \mu \mathrm{M}$ oligomycin, $2 \mu \mathrm{M}$ rotenone and 5 $\mathrm{mM}$ succinate, and mitochondrial swelling was monitored at $25^{\circ} \mathrm{C}$ as the absorbance decrease at 546 $\mathrm{nm}$, as in [9].

2.13 Statistical analysis and computing. All statistical analyses in this study were performed using SPSS software. The data were representative of at least three independent experiments carried out with different neuronal preparations, and are reported as the mean with the standard deviation (S.D.). Statistical significance of the data was evaluated using the one-way analysis of variance (ANOVA) followed by the post-hoc Bonferroni test. $p<0.05$ was considered as significant for all analyses.

Experimental plots were obtained using Grafit (Erithacus software).

\section{Results.}

\subsection{Flavonoids and low-K+ induced CGC apoptosis.}

7 DIV neuron cultures were kept either in high potassium medium (S-K25 cells) or subjected to low potassium shift (S-K5 cells), which is responsible for triggering apoptosis (for ref see 6, 35), in the absence or presence of a variety of flavonoids. That neurons died via apoptosis was confirmed by monitoring DNA laddering, which is a specific hallmark of apoptosis (Fig. 1A), and the sensitivity of death to the transcriptional inhibitor Act D (Fig. 1B). DNA laddering was found only in S-K5 cells (Fig. 1A, lane b), but was completely prevented in the presence of the transcriptional inhibitor Act D (1 $\mu \mathrm{g} / \mathrm{ml})$ (Fig. 1A, lane d). That necrosis had not occurred was shown by the absence of significant LDH activity, both in S-K5 and S-K25 culture medium up to 15 hrs (not shown), and by the insensitivity of death to MK801, a selective NMDA receptor antagonist, which prevents glutamate-dependent necrosis [for ref, see 44, 47]. 
In Fig. 1B, we further confirmed that CGC death occurred via apoptosis, as shown by its complete prevention by Act D (1 $\mathrm{g} / \mathrm{ml})$ (see [35]), but not by MK801 (1 $\mu \mathrm{M})$. In fairly good agreement with $[9,35]$, the survival of S-K5 CGC $24 \mathrm{~h}$ after apoptosis induction was $40 \%$ with respect to the control $(p<0.001,6$ expts). Next, we investigated whether the isoflavones GEN and DZN could prevent CGC apoptosis, as observed $24 \mathrm{~h}$ after induction. The effect of epicatechin (EC) and catechin (CE) was also investigated (Fig. 1B). In all cases, the compounds were added at concentrations of up to $20 \mu \mathrm{M}$; they had no effect on S-K25 CGC survival (not shown).

GEN and DZN $(0.1-20 \mu \mathrm{M}$ each) proved to prevent death in a dose-dependent manner, with a survival of about $70 \%(p<0.001,6$ experiments $)$ in the presence of $20 \mu \mathrm{M}$ GEN, and about $60 \%$ $(p<0.01,6$ experiments) in the presence of $20 \mu \mathrm{M}$ DZN. Treatment with Act D in the presence of flavonoid resulted in the complete prevention of death; this confirms that death occurred by apoptosis. In contrast, both EC and CE, used at concentrations of up $20 \mu \mathrm{M}$, were totally ineffective (Fig. 1B). Death prevention was confirmed in a parallel experiment in which phase-contrast micrographs of the cells were used, as in [48]. Fig. 1C shows that both GEN (panel $\boldsymbol{c}$ ) and DZN (panel $\boldsymbol{d})(20 \mu \mathrm{M}$ each) treatment resulted in a reduction of cell degeneration and death with respect to untreated S-K5 cells (panel $\boldsymbol{b}$ ).

Having established that GEN and DZN can prevent apoptosis of CGCs, their effects on some mitochondria-linked steps in the process leading to apoptosis of CGCs were investigated separately.

\subsection{Glucose oxidation by either GEN- or DZN-S-K5 cells.}

The ability of GEN and DZN to prevent the impairment of glucose oxidation, which occurs in early apoptosis [5], was investigated. Oxidation of externally added glucose (10 mM) by intact cells was monitored by measuring the oxygen consumption that results from glucose uptake by CGCs, 
followed by aerobic glycolysis, citric acid cycle action and electron flow along the mitochondrial respiratory chain. In a typical experiment (Fig. 2) the oxygen uptake rates were about 55 and 36 natom $\mathrm{O} / \mathrm{min}$ per mg cell protein for S-K25 and $3 \mathrm{~h}$ S-K5 CGCs, respectively. In both cases, cyanide $\left(\mathrm{CN}^{-}\right)$, which prevents electron flow by blocking cytochrome oxidase activity, and ouabain, which can prevent glucose uptake by preventing cellular sodium/potassium ATPase [for ref see 5] (not shown), completely inhibited oxygen consumption. In 3 h-S-K5 cells, the decrease in the oxygen consumption rate was largely prevented by either GEN or DZN (20 $\mu \mathrm{M}$ each); the rates were 49 and 44 natom $\mathrm{O} / \mathrm{min}$ per $\mathrm{mg}$ cell protein, respectively (Fig. 2). Notice that the glucose oxidation rate remained constant in S-K25 CGCs up to $3 \mathrm{~h}$. As a result of treatment of the cells with superoxide dismutase (SOD, E.C.1.15.1.1, $50 \mathrm{U} / \mathrm{ml}$ ), which was added to S-K5 cell cultures, the impairment of glucose oxidation was prevented, with an oxygen uptake rate by CGCs equal to 51 natom O/min per mg cell protein) (inset to Fig. 2).

In a set of similar experiments with GEN and DZN concentrations ranging from 0.1 to $20 \mu \mathrm{M}$, we found that isoflavone prevention of the impairment of glucose oxidation was dose-dependent (see panel B of Fig. 2). GEN proved to be more effective than DZN, as judged by a statistical analysis carried out according the Bonferroni test.

\subsection{Mitochondrial coupling in either GEN- or DZN-S-K5 cells.}

In another set of experiments (Fig. 3), mitochondrial coupling in the homogenates of either S-K25 or $3 \mathrm{~h}-\mathrm{S}-\mathrm{K} 5 \mathrm{CGCs}$ incubated in the absence or presence of either GEN or DZN was investigated. To achieve this, oxygen uptake was measured arising from the addition of succinate to cell homogenate in either the absence (state 4) or presence (state 3) of ADP (1 mM) used to stimulate oxidation. The RCR values (oxygen uptake in state 3)/(oxygen uptake rate in state 4), which reflect the ability of 
mitochondria to produce ATP, were about 5.0, 2.6, 4.2 and 3.5 in S-K25, 3 h-S-K5, GEN- and DZN-3h-S-K5 (20 $\mu \mathrm{M}$ each) cells, respectively. When SOD (50 U/ml) was added to S-K5 cell culture, the RCR value was 4.5 (inset to Fig. 3).

Notice that the rate of oxygen uptake in state 4 was not changed by treatment with either GEN or DZN, ruling out the possibility that these compounds can uncouple mitochondria. In a control experiment, we found that GEN and DNZ were without effect when oxygen uptake by S-K25 cell homogenates was investigated.

In panel B of Fig. 3, the RCR values (calculated from 5 expts) obtained using GEN or DZN concentrations ranging from 0.1 to $20 \mu \mathrm{M}$ are reported. Fig. $3 \mathbf{B}$ shows that the prevention of mitochondrial impairment was dose-dependent, with GEN more effective that DZN.

Other mitochondrial steps of CGC apoptosis were investigated separately at $3 \mathrm{~h}$ and/or $5 \mathrm{~h}$ after apoptosis induction, times which reflect the early and the late phases of apoptosis, respectively (see above).

\subsection{The release of cytochrome c from either GEN- or DZN-S-K5 cell mitochondria.}

Since in CGC apoptosis the release of cyt $c$ from mitochondria occurs as a result of extra ROS production [for refs, see $7,49,50$ ], the ability of either GEN or DZN to affect cyt $c$ release was investigated (Fig. 4). To do this, as in $[46,50]$, we resorted to polarographic measurement of the activation of cyt $c$-dependent ASC oxidation, which itself confirmed that cyt $c$ was released in an active form [50] (for details see the methods). In a typical experiment, S-K25, S-K5, GEN-S-K5 or DZN-S-K5 cells, at $3 \mathrm{~h}$ after apoptosis induction, were compared to one another with respect to their ability to oxidize externally added ASC (5 mM) (Fig. 4A). No oxygen uptake was found in the SK25 cell sample in the presence of ASC alone (trace a), showing that mitochondria were intact and 
that no release of cyt $c$ had occurred. ASC addition to homogenates from S-K5, GEN- or DZN-S-K5 CGCs resulted in oxygen uptake at a rate of about 16,8 and 11 natom $\mathrm{O} / \mathrm{min} \mathrm{x}$ mg cell protein, respectively (traces $b$ - $d$ ). The results in Fig. $\mathbf{4 A}$ show that prevention of cyt $c$ release occurred as a result of the presence of the flavonoids. The prevention was dose-dependent (Fig. 4B), with GEN being more effective than DZN; prevention values were about $50 \%$ and $25 \%$ in the GEN- and DZNS-K5 cells $(20 \mu \mathrm{M}$ each), respectively. As a control, the occurrence of $60 \%$ prevention of cyt $c$ release in S-K5 cells in the presence of externally added SOD was confirmed [6].

\subsection{ATP level, ANT activity and mPTP opening in either GEN- or DZN-S-K5 cells.}

ATP is required for apoptosis to occur. In early apoptosis, ATP is mostly produced in the mitochondria by oxidative phosphorylation [8] and is exported via the ANT into the cytoplasm [for refs, see 9]. As in [8], we found that the ATP level in 3 h-S-K5 CGCs was higher compared with the control (1.2 vs. $0.7 \mathrm{nmol} / \mathrm{mg}$ cell protein); incubation of S-K5 cells with GEN or DZN (20 $\mu \mathrm{M}$ each) or SOD (50 $\mathrm{U} / \mathrm{ml}$ ) did not result in a change of the ATP level (Fig. 5A).

The effect of GEN and DZN on the process in which alteration of the ANT takes place, triggering opening of mPTP [see above and 9], was investigated by measuring in parallel both ANT-mediated transport and mPTP opening in S-K25, S-K5, GEN-S-K5 and DZN-S-K5 cell homogenates. This was done both at $\mathbf{3} \mathbf{h}$, when ANT function is impaired due to ROS, but no MPTP opening occurs, and at $\mathbf{5} \mathbf{h}$, when further caspase-dependent ANT impairment occurs and MPTP opening initiates [9]. In the inset, GEN and DZN were present at concentrations equal to $20 \mu \mathrm{M}$, when ANT function is impaired due to ROS, but no mPTP opening occurs, and at $\mathbf{5} \mathbf{h}$, when further caspase-dependent ANT impairment occurs and mPTP opening initiates [9]. In the former case, we resorted to a procedure (see [9]) that allows for the continuous monitoring of ATP efflux from mitochondria 
incubated with ADP; in the latter, mPTP opening was investigated as mitochondrial swelling as in [9] (for details see the methods). In a typical experiment, cell homogenates were treated with AP5A to inhibit adenylate kinase. In all cases, the ATP concentration outside the mitochondria was negligible, as no increase in the absorbance measured at $334 \mathrm{~nm}$ was found in the presence of the ATP D.S. As a result of the addition of ADP $(0.04 \mathrm{mM})$, an increase in the NADPH absorbance was found, indicating the appearance of ATP in the extramitochondrial phase. The explanation for this is as follows (see Fig. 5B): ADP enters mitochondria in exchange for endogenous ATP; inside the matrix ATP is synthesized by oxidative phosphorylation, and the newly synthesized ATP exits the mitochondria in exchange for further ADP via the ANT. That the rate of NADPH formation mirrored, in all cases, the rate of ADP/ATP exchange was confirmed by applying control flux analysis as in [9] (not shown). The rates of ATP efflux were 10, 2.5 and 1.6 nmol NADP reduced/min x mg cell protein for S-K25, 3h-S-K5 and 5h-S-K5 CGCs, respectively (Fig. 5C, D). When SOD $(50 \mathrm{U} / \mathrm{ml})$ was added to the cell cultures, almost complete prevention of ANT impairment was found at $3 \mathrm{~h}$ after apoptosis induction $\left(10 \mathrm{nmol} \mathrm{NADP}^{+}\right.$reduced/min $\mathrm{x} \mathrm{mg} \mathrm{cell)}$ (Fig. 5C); this confirmed that the decrease in ANT efficiency depended on extra ROS production [9]. In 5h-S-K5 cells, where a progressive impairment in ANT occurs mainly due to caspase activation, the SOD prevention decreased to $5.3 \mathrm{nmol} \mathrm{NADP}^{+}$reduced/min $\mathrm{x} \mathrm{mg} \mathrm{cell} \mathrm{(Fig.} \mathrm{5D).}$ In GEN-3h-S-K5, GEN 5h-S-K5, DZN 3h-S-K5 and DZN 5h-S-K5 CGCs (20 $\mu$ M each), the rates of ATP efflux were 9.3, 4.0, 5.9 and 3.6 $\mathrm{nmol} \mathrm{NADP}^{+}$reduced/min x mg cell protein, respectively (Fig. 5C,D). This shows that both GEN and DZN can prevent ANT impairment.

In a parallel experiment (Fig. 6), mPTP opening was measured by monitoring mitochondrial swelling as a change in absorbance at $546 \mathrm{~nm}$ of the CGC homogenate (see Method Section). It should be noted that the decrease in light absorbance is a spontaneous process due to apoptosis and is not 
calcium-dependent [see 51]. As in [9], no mPTP opening was found at $3 \mathrm{~h}$ after induction of apoptosis, either in the absence or presence of GEN or DZN (not shown), confirming that ROS themselves cannot cause mPTP opening. In 5h-SK5 CGCs, mPTP opening occurred. In either GENor DZN-S-K5 cells, mPTP opening was prevented in a manner dependent on the compound concentration, with 70 and $50 \%$ prevention found for GEN and DZN, respectively, at a concentration of $20 \mu \mathrm{M}$. In SOD $(50 \mathrm{U} / \mathrm{ml})$ treated cells, $80 \%$ prevention was found. As expected, no mitochondrial swelling occurred in the presence of $1 \mu \mathrm{M}$ cyclosporine $\mathrm{A}$ (CsA), an inhibitor of $\operatorname{mPTP}[9,52]$.

\subsection{Superoxide anion production in either GEN- or DZN-S-K5 cells}

In CGC apoptosis, extra ROS production takes place $[6,53$ and refs therein] with all of the above steps shown to be mostly dependent on ROS production. Since both GEN and DZN are antioxidants, we investigated whether they, used up to $20 \mu \mathrm{M}$, could decrease $\mathrm{O}_{2}^{-}$. levels at $3 \mathrm{~h}$ into apoptosis, when maximum $\mathrm{O}_{2}^{-}$production takes place [6] (Fig. 7). In agreement with [6], the superoxide level $\left(4.0 \pm 0.1 \mathrm{nmol} \mathrm{O}_{2}^{-} / 10^{6}\right.$ cells) was substantially decreased by externally added SOD $(p<0.001)$. A dose-dependent decrease in $\mathrm{O}_{2}^{-\cdot}$ levels was found in both GEN- or DZN-S-K5 cells; in GEN (10 $\mu \mathrm{M})$ and DZN $(20 \mu \mathrm{M})-\mathrm{S}-\mathrm{K} 5$ cells, the level of $\mathrm{O}_{2}{ }^{-\cdot}$ was reduced by about $50 \%$.

Since in S-K5 cells XO can contribute to ROS production [49], and since GEN was reported to be a XO inhibitor $[32,33]$, we investigated whether GEN could inhibit XO in S-K5 cells. To do this we resorted to a procedure in which $\mathrm{XO}$ was assayed fluorimetrically by monitoring the increase in fluorescence arising from the formation of isoxanthopterin from pterine (PTE) [45]. The rates of isoxanthopterin generation were about 14 and $6 \mathrm{nmol} / \mathrm{min} \mathrm{x}$ mg cell protein for $3 \mathrm{~h} \mathrm{S-K5}$ and S-K25 cells, respectively (Fig. 8Aa,b). In GEN-3h-S-K5 cells, no inhibition of the fluorescence increase 
(Fig. 8Aa) due to pterine addition to the cell homogenate occurred, showing that GEN itself had no effect on XO activity. This was also confirmed when GEN was added to the assay mixture before starting the reaction (Fig. 8Ab) . As a control, we confirmed that the reaction was strongly inhibited by allopurinol, a specific XO inhibitor [see 44, 45], either incubated with cultured cells (a) or added during the reaction (b). As expected, no change in the XO reaction was found in SOD-treated CGCs (not shown).

In parallel, we assayed XO by adding xanthine $(10 \mu \mathrm{M})$ plus $\mathrm{Fe}^{3+}$-cyt $c$ to the homogenates. In this system, $\mathrm{O}_{2}^{-}$formation due to endogenous $\mathrm{XO}$ was measured as an absorbance increase at $550 \mathrm{~nm}$ resulting from reduction of $\mathrm{Fe}^{3+}$-cyt $c$ (Fig. 8B). The rates of $\mathrm{O}_{2}{ }^{-\cdot}$ formation, equal to 10 and 2.5 $\mathrm{nmol} / \mathrm{min} \mathrm{x}$ mg cell protein in $3 \mathrm{~h}-\mathrm{S}-\mathrm{K} 5$ and $\mathrm{S}-\mathrm{K} 25$, respectively, were decreased by $60 \%$ by GEN $(20 \mu \mathrm{M})$ incubated with $3 \mathrm{~h} \mathrm{S-K5-cells} \mathrm{(a)} \mathrm{or} \mathrm{added} \mathrm{before} \mathrm{the} \mathrm{reaction} \mathrm{was} \mathrm{started} \mathrm{(b).} \mathrm{The} \mathrm{rates}$ were decreased to zero $(\boldsymbol{a}, \boldsymbol{c})$ or partially decreased $(\boldsymbol{b})$ by allopurinol $(10 \mu \mathrm{M})$ and SOD $(50 \mathrm{U} / \mathrm{ml})$, respectively.

These data suggest that GEN cannot inhibit XO itself, even if it can scavenge ROS. Surprisingly enough with respect to the above experiment, but in agreement with $[32,33]$, we found that GEN can inhibit commercial XO activity as assayed either fluorimetrically or photometrically (not shown).

\section{Discussion}

We show here that both GEN and its analogue DZN, used at dietary concentrations, can prevent low potassium-dependent apoptosis in CGCs, and may perhaps be of use in neuroprotection. Indeed, the flavonoid effect proved to be rather specific; in spite of their shared antioxidant capability, GEN and DZN, but not CE and EC, prevented CGC death. (Fig. 1). On the other hand, a comparison made between GEN and CE showed that GEN could prevent cell death both in CGCs and in rat 
mesencephalic cultures, whereas CE was effective only in the latter case [54]. Hence, the flavonoid effect depends on the experimental system investigated.

Since prevention of apoptosis occurred with a parallel prevention of the impairment of certain steps of the mitochondrial pathway to apoptosis, we conclude that the effects of both GEN and DZN involve CGC mitochondria. In fact, we found prevention of the impairment of both aerobic glucose metabolism and, more importantly, of the mitochondrial uncoupling that occurs in apoptosis (Fig. 23) in the presence of these compounds. We also found the prevention of cyt $c$ release (Fig. 4), ANT alteration (Fig. 5) and mPTP opening (Fig. 6). Finally, because the above steps of the mitochondrial pathway to apoptosis are somehow related to ROS production, which takes place during apoptosis, and since both GEN and DZN proved to decrease ROS levels (Fig. 7), we strongly suggest that the prevention of apoptosis is essentially due to the antioxidant properties of the flavonoids. This is supported by the evidence that the effects of GEN and DZN parallel those produced by the antioxidant SOD [see 6]. Thus, although other effects of GEN as a dietary compound inducing hormonal, metabolic and expression changes $[55,56]$ cannot be ruled out, we maintain that its role as an antioxidant is crucial in accounting for these experimental findings. Accordingly, we first showed that these compounds can remove the extra ROS produced in cells undergoing apoptosis (Fig. 7). Whether the mechanism by which GEN decreases ROS levels in CGC apoptosis includes other effects remains a matter of speculation. For instance, proteosomal inhibition by GEN could cause an increase in the scavenging efficiency of the cell antioxidant system targeted by proteosoma en route to apoptosis [see 6]. In addition, the antioxidant properties of GEN and DZN could result from enhancement of the activities of other antioxidant molecules and enzymes (superoxide dismutase, glutathione peroxidase and reductase) both in vitro and in vivo [30, 57]. In particular, DZN was shown to decrease the GSH/GSSG ratio, suggesting that it could have pro-oxidant effects in the brain [58]. 
Since GEN is relatively more effective at inhibiting hydroxyl radical-induced oxidation compared with DZN, which is the stronger agent against superoxide radical-induced oxidation [59], we might speculate that the greater protection against apoptosis provided by GEN suggests a special role for hydroxyl radicals in apoptosis. GEN and DZN differ from one another with respect to other biological activities. For example, in distinction from DZN, GEN is a strong inhibitor of TK [19]. Since DZN is also neuroprotective, we assume that the inhibition of TK has no/minimal role in preventing apoptosis. In this regard, it should be noted that in normal cells TK activity is rather poor, whereas in tumor cells, TK activity can increase 10-20 times [60]. Hence, the activity of GEN in cancer chemoprevention could arise from the inhibition of TK [61].

In CGCs, the ATP level proved to be insensitive to GEN and DZN (Fig. 5A). On the other hand, GEN was shown to enhance mitochondrial energy metabolism by increasing ATP synthesis in the neurodegeneration of ovariectomized rats, as reported by Shi et al. [62]. Indeed, several flavonoids proved to increase cellular ATP levels, possibly by increasing ATP production via oxidative phosphorylation [63]. In our case, because mitochondrial impairment in apoptosis is somehow prevented by these isoflavones, we suggest that oxidative phosphorylation contributes more significantly to ATP production, which is normally counterbalanced by anaerobic glycolysis, leading to extra production of L-lactate in apoptosis $[4,8]$.

As expected, because of their role as antioxidants, GEN and DZN were found to almost completely prevent the alteration of ANT, which occurs in apoptosis (Fig. 5), as investigated in 3h-S-K5 CGCs when ROS alone affects the molecule. The effect was only partial at $5 \mathrm{~h}$ when a further progressive decrease in the ANT function occurs arising from caspase-dependent proteolysis. Conversely, at $5 \mathrm{~h}$ after apoptosis induction, GEN and DZN partially prevented mPTP opening, as occurs with SOD (Fig. 6). Since neither GEN nor DZN proved to have any effect on ATP levels in S-K25 cells, we 
conclude that their effects are a result of the prevention of oxidative damage to mitochondria rather than to broad activation.

We have also shown that GEN can reduce ROS levels in S-K5 cells. This does not depend on the inhibition by GEN of XO, which in distinction with [21], does not occur in CGCs. The reason for this anomaly is under investigation; it may be possible that the $\mathrm{XO}$ domain where GEN binds, thus causing competitive inhibition [see 21], is protected by a high xanthine concentration, perhaps due to microcompartmentation or by other unknown cell component/s.

Comparison of the results reported in this paper with those of others shows that any effect due to either GEN or DZN depends on their concentrations. Cell treatment with GEN at high non-dietary concentrations results in a variety of different effects, including ATP synthase inhibition [13], mPTP opening [15] and apoptosis induction [14].

The clear lesson is that simple generalizations of the roles of these compounds cannot be made [22]. Their effects depend on a variety of factors that are related to the experimental system investigated and the flavonoid concentrations used.

\section{Figure legends.}

\section{Graphical Abstract legend}

GEN and DZN reduce the levels of ROS, the release of cytochrome $c$, the impairment of ANT, the opening of mPT and apoptotic death in CGCs.

\section{FIGURE 1. The effect of some flavonoids on low-K ${ }^{+}$induced CGC apoptosis}

Rat CGCs (1 x 10\% 1 well) at 7 DIV were incubated either in high potassium (S-K25) or low potassium (S-K5) serum-free culture medium. 
A) DNA fragmentation. Soluble DNA was extracted from neurons switched to serum-free culture medium containing low $\mathrm{K}^{+}(5 \mathrm{mM})$ in the absence (lane $\left.\boldsymbol{b}\right)$ or presence of Act $\mathrm{D}(1 \mu \mathrm{g} / \mathrm{mL}$; lane $\boldsymbol{d})$ after $15 \mathrm{~h}$. Lane $\boldsymbol{c}$ contains DNA from control cells maintained in high $\mathrm{K}^{+}(25 \mathrm{mM})$ for $15 \mathrm{~h}$. DNA from equal numbers of plated cells $\left(6 \times 10^{6}\right)$ was loaded in each lane. Size marker was HaeIIIdigested $\Phi \times 174$ phage DNA (lane a).

B) Survival: S-K5 cells were incubated in the absence (None) or presence of the following compounds: genistein (GEN), daidzein (DZN), epicatechin (EC) and catechin (CE) at the indicated concentrations. Where indicated, $1 \mu \mathrm{M}$ MK801 and $1 \mu \mathrm{g}$ Act D were present in the culture medium. At $24 \mathrm{~h}$, the viability of S-K25 and S-K5 cells was determined by counting the number of intact nuclei. Cell viability was expressed as the percentage of that of the S-K25 cells. Control values were 100 \pm 10 . The compounds used had no effect on the survival of S-K25 cells. Results are means with the ( \pm S.D.) of triplicate measurements and are representative of six different experiments carried out with different cell preparations from different groups of animals.

ANOVA and Bonferroni test: ${ }^{(*)}(* *)(* * *)$ statistically significantly different with $p<0.05, p<0.01$ and $p<0.001$, respectively, when S-K5 cells were compared against the samples indicated with asterisk/s. The lack of asterisk indicates no statistically significant differences.

C. Phase-contrast micrographs showing neurons maintained for $24 \mathrm{~h}$ in serum-free medium containing $25 \mathrm{mM} \mathrm{KCI} \mathrm{(a)} \mathrm{and} 5 \mathrm{mM} \mathrm{KCl}$ in the absence (b) or presence of either GEN (c) or DZN (d) $(20 \mu \mathrm{M}$ each). The phase contrast micrograph was taken using a NIKON DIAPHOT TS-100 epifluorescence microscope (equipped with a 40 x objective). Images were digitized by using a Nikon Digital Video Camera E995 (Coolpix 995).

Figure 2. Glucose oxidation by either GEN- or DZN-S-K5 cells. 
A) Rat CGCs $\left(2 \times 10^{6} /\right.$ well) at 7 DIV were switched from high potassium (25 mM) (S-K25) (a) to low potassium $(5 \mathrm{mM})$ serum-free culture medium in the absence (S-K5) or presence of $20 \mu \mathrm{M}$ genistein (GEN-S-K5) or $20 \mu \mathrm{M}$ daidzein (DZN-S-K5) for 3 hours. Aliquots corresponding to 0.2 mg cell protein were incubated at $25^{\circ} \mathrm{C}$ in a water-jacketed glass vessel to monitor $\mathrm{O}_{2}$ consumption polarographically. Glucose $(10 \mathrm{mM})$ and subsequent $\mathrm{CN}^{-}(1 \mathrm{mM})$ additions were made at the indicated times. In the inset, S-K5 cells were treated with SOD (50 U/ml) (SOD-S-K5). Numbers along the curves are rates of oxygen uptake expressed as natom $\mathrm{O} / \mathrm{min} \times \mathrm{mg}$ cell protein.

B) The dependence of the rates of glucose-dependent oxygen consumption $\left(\mathbf{V}_{\mathbf{O} 2}\right.$ glucose $)$ versus GEN and DZN concentrations is reported. Data are the mean \pm S.D. of five measurements and are representative of at least three different experiments carried out with different cell preparations.

ANOVA and Bonferroni test: ${ }^{(*)}{ }^{(*)}$ statistically significantly different with $p<0.05$ and $p<0.01$, respectively, when S-K5 cells were compared against the samples indicated with asterisk/s. The lack of asterisk indicates no statistically significant differences.

\section{Figure 3. Mitochondrial coupling in either GEN- or DZN-S-K5 cells.}

A) Rat CGCs $\left(2 \times 10^{6} /\right.$ well $)$ at 7 DIV, switched from high potassium (25 mM) (S-K25) (a) to low potassium $(5 \mathrm{mM})$ serum-free culture medium in the absence (S-K5) or presence of $20 \mu \mathrm{M}$ genistein (GEN-S-K5) or $20 \mu \mathrm{M}$ daidzein (DZN-S-K5) for 3 hours, were homogenized and incubated $(0.2$ mg cell protein) at $25^{\circ} \mathrm{C}$ in a water-jacketed glass vessel and the consumption of $\mathrm{O}_{2}$ was monitored polarographically. Succinate (SUCC, $5 \mathrm{mM})$ and ADP $(1 \mathrm{mM})$ were added at the indicated times. In the inset, S-K5 cells were treated with SOD (50 U/ml) (SOD-S-K5). Numbers along the curves are rates of oxygen uptake expressed as natom $\mathrm{O} / \mathrm{min} \times \mathrm{mg}$ cell protein. 
B) The dependence of Respiratory Control Ratio (RCR) values versus GEN and DZN concentrations is reported. Data are the mean \pm S.D. of five measurements and are representative of at least three different experiments carried out with different cell preparations.

ANOVA and Bonferroni test: ${ }^{(*)}(* *)(* * *)$ statistically significantly different with $p<0.05, p<0.01$ and $p<0.001$, respectively, when S-K5 cells were compared against the samples indicated with asterisk/s. The lack of asterisk indicates no statistically significant differences.

Figure 4. The release of cytochrome c from either GEN- or DZN-S-K5 cell mitochondria.

Rat CGCs $\left(2 \times 10^{6} /\right.$ well) at 7 DIV were incubated in either high potassium (S-K25) or low potassium serum-free culture medium in the absence (S-K5) or presence of either genistein (GENS-K5), daidzein (DZN-S-K5) or SOD (50/ml) (SOD-S-K5). At 3 hours after apoptosis induction, the cells were scraped, collected and homogenized. Cell homogenate (about $0.2 \mathrm{mg}$ protein) was incubated at $25^{\circ} \mathrm{C}$ in the presence of $3 \mu \mathrm{M}$ rotenone, $0.8 \mu \mathrm{M}$ antimycin and $6 \mu \mathrm{M}$ myxothiazole in a water-jacketed glass vessel.

A) Cyt $c$ release from S-K25 or S-K5 cells, in the absence or presence of GEN and DZN (20 $\mu \mathrm{M}$ each), at $3 \mathrm{~h}$ after apoptosis induction, was detected by means of oxygen consumption caused by externally added ASC (5 mM).

B) Cyt $c$ release from $\mathrm{S}-\mathrm{K} 25$ or $\mathrm{S}-\mathrm{K} 5$ cells, in the absence or presence of GEN and DZN at the indicated concentrations, at $3 \mathrm{~h}$ after apoptosis induction, was detected as in A). Results, expressed as natoms $\mathrm{O} / \mathrm{min} \mathrm{x} \mathrm{mg}$ cell protein, are the means \pm S.D. of triplicate measurements and are representative of at least six different experiments carried out with different cell preparations obtained from different groups of animals. 
ANOVA and Bonferroni test: $\left.{ }^{*}\right)(* *)(* * *)$ statistically significantly different with $p<0.05, p<0.01$ and $p<0.001$, respectively, when S-K5 cells were compared against the samples indicated with asterisk/s. The lack of asterisk indicates no statistically significant differences.

Figure 5. ATP level and ANT activity in homogenates from either GEN-or DZN-S-K5 cells.

A. The amounts of ATP were measured by HPLC in neutralized perchloric acid extracts of either SK25 or S-K5 CGCs in the absence or presence of GEN $(20 \mu \mathrm{M})$, DZN (20 $\mu \mathrm{M})$ or SOD $(50 \mathrm{U} / \mathrm{ml})$, as described in the Methods section.

ANOVA and Bonferroni test: No statistically significant differences were found when S-K5 cells were compared against each sample.

B. The scheme describes the method used to detect ATP appearance in the extramitochondrial phase due to the addition of ADP to CGC homogenate.

C-D. Appearance of ATP due to the addition of ADP $(0.04 \mathrm{mM})$ to CGC homogenate $(0.1 \mathrm{mg}$ protein) from S-K25 or S-K5 cells in the absence or presence of GEN and DZN at the indicated concentrations at 3 (A) and 5 hours (B) after apoptosis induction was monitored as described in the Methods.

Figure 6. mPTP opening in homogenates from either GEN- or DZN-S-K5 cells.

Rat CGCs $\left(15 \times 10^{6} /\right.$ well) at 7 DIV were incubated either in high potassium (S-K25) or low potassium (S-K5) serum-free culture medium in the absence or presence of either GEN or DZN at the indicated concentrations, or SOD $(50 \mathrm{U} / \mathrm{ml})$ or cyclosporine $\mathrm{A}(\mathrm{CsA}, 1 \mu \mathrm{M})$ for 8 hours. mPTP opening was monitored by mitochondrial swelling (see the Methods section).

Figure 7. Superoxide anion production in either GEN- or DZN-S-K5 cells. 
Rat CGCs $\left(0.5 \times 10^{6} /\right.$ well) at 7 DIV were incubated in either high potassium (S-K25) or low potassium (S-K5) serum-free culture medium containing $\mathrm{Fe}^{3+}$-cyt $c(10 \mu \mathrm{M})$ in the absence or presence of either GEN or DZN at the indicated concentrations or SOD (50 U/ml). At 3 hours after apoptosis induction, the culture solution was taken and the increase in absorbance at $550 \mathrm{~nm}$ due to $\mathrm{Fe}^{3+}$-cyt $c$ reduction was determined. The experimental data are reported as nmol ROS formed \pm S.D. $/ 10^{6}$ cells, calculated on the basis of the stoichiometry of the reaction using the extinction coefficient determined under our experimental conditions (see Methods). The experiment was repeated 4 times with different cell preparations.

ANOVA and Bonferroni test: $\left.{ }^{*}\right)(* *)(* * *)$ statistically significantly different with $p<0.05, p<0.01$ and $p<0.001$, respectively, when S-K5 cells were compared against the samples indicated with asterisk/s. The lack of asterisk indicates no statistically significant differences.

\section{Figure 8. Xanthine oxidase activity in GEN-S-K5 cells.}

Rat CGCs $\left(3 \times 10^{6} /\right.$ well) at 7 DIV were switched from high potassium $(25 \mathrm{mM})$ (S-K25) to low potassium $(5 \mathrm{mM})$ serum-free culture medium (S-K5). After 3 hours of incubation, CGCs were collected and homogenized in PBS. The protein concentration was adjusted to $25 \mu \mathrm{g} / \mathrm{ml}$ and aliquots were then assayed for XO activity.

A) The fluorimetric increase due to isoxanthopterine formation $(345 / 390 \mathrm{~nm})$ was initiated by the addition of pterine $(10 \mu \mathrm{M})$ (see the Methods section). In $\boldsymbol{a}$ ) either $20 \mu \mathrm{M}$ GEN (GEN-S-K5) or 10 $\mu \mathrm{M}$ allopurinol (ALLO-S-K5) was added to the cell well at the same time as the switch in $\mathrm{K}^{+}$ concentration. In b) $20 \mu \mathrm{M}$ GEN or $10 \mu \mathrm{M}$ ALLO was added to the S-K5 suspension before pterine addition or during the reaction, respectively. Numbers along the traces are values of XO activity expressed as nmol of isoxanthopterin formed/min x mg cell protein. 
B) Both S-K5 and S-K25-CGCs were incubated with $\mathrm{Fe}^{3+} \mathrm{Cyt} c(10 \mu \mathrm{M})$. The absorbance increase due to $\mathrm{Fe}^{3+} \mathrm{Cyt} c(550 \mathrm{~nm})$ reduction was initiated by the addition of xanthine (XANT, $10 \mu \mathrm{M}$ ) (see the Methods section). In $\boldsymbol{a}$ ) and $\boldsymbol{b}$ ) either $20 \mu \mathrm{M}$ GEN (GEN-S-K5), $10 \mu \mathrm{M}$ allopurinol (ALLO-SK5) or SOD (50 U/ml) (SOD-S-K5) was added to the cell well at the same time as the switch in $\mathrm{K}^{+}$ concentration. In c) $20 \mu \mathrm{M}$ GEN and $10 \mu \mathrm{M}$ ALLO was added to the S-K5 suspension before XANT addition. Numbers along the traces are values of $\mathrm{XO}$ activity expressed as $\mathrm{nmol}_{2}{ }^{-}$ formed/min x mg cell protein.

Acknowledgements. The authors thank Prof. Shawn Doonan for his critical reading of the manuscript and Mr. Vito Petragallo (IBBE, CNR) for his skilful technical assistance with tissue culture.

This work was partially financed by FIRB RBNE03B8KK_003, Fondi di Ricerca di Ateneo del Molise (to S.P.) and MIUR - Contributi straordinari di ricerca/aree obiettivo 1 (to E.M.).

\section{REFERENCES.}

1. Alenzi FQ. Apoptosis and diseases: regulation and clinical relevance. Saudi Med J 2005; 26:1679-1690.

2. Martin KR Targeting apoptosis with dietary bioactive agents. Exp Biol Med 2006; 231:117129.

3. Zhao B. Natural antioxidants protect neurons in Alzheimer's disease and Parkinson's disease. Neurochem Res 2009; 34:630-638.

4. Atlante A, de Bari L, Bobba A, Marra E, Passarella S. Transport and metabolism of L-lactate occur in mitochondria from cerebellar granule cells and are modified in cells undergoing low potassium dependent apoptosis. Biochim Biophys Acta 2007; 1767:1285-1299.

5. Atlante A, Gagliardi S, Marra E, Calissano P. Neuronal apoptosis in rats is accompanied by rapid impairment of cellular respiration and is prevented by scavengers of reactive oxygen species. Neurosci Lett 1998; 245:127-130.

6. Atlante A, Bobba A, Calissano P, Passarella S, Marra E. The apoptosis/necrosis transition in cerebellar granule cells depends on the mutual relationship of the antioxidant and the proteolytic systems which regulate ROS production and cytochrome c release en route to death. J Neurochem 2003; 84:960-971. 
7. Bobba A, Atlante A, Giannattasio S, Sgaramella G, Calissano P, Marra E. Early release and subsequent caspase-mediated degradation of cytochrome $c$ in apoptotic cerebellar granule cells. FEBS Lett 1999; 457:126-130.

8. Atlante A, Giannattasio S, Bobba A, Gagliardi S, Petragallo V, Calissano P, Marra E, Passarella S. An increase in the ATP levels occurs in cerebellar granule cells en route to apoptosis in which ATP derives from both oxidative phosphorylation and anaerobic glycolysis. Biochim Biophys Acta 2005; 1708:50-62.

9. Atlante A, Bobba, de Bari L, Fontana F, Calissano P, Marra E, Passarella S. Caspasedependent alteration of the ADP/ATP translocator triggers the mitochondrial permeability transition which is not required for the low-potassiumdependent apoptosis of cerebellar granule cells. J Neurochem 2006; 97:1166-1181.

10. Spencer JPE. Food for thought: the role of dietary flavonoids in enhancing human memory, learning and neuro-cognitive performance. Proc Nutr Soc 2008; 67:238-252.

11. Spencer JPE. Flavonoids: modulators of brain function? Br J Nutr 2008; 99 E-Suppl. $1:$ :ES6-ES77.

12. Barnes S, Boersma B, Patel R, Kirk M, Darley-Usmar VM, Kim H, Xu J. Isoflavonoids and chronic disease: mechanisms of action. Biofactors 2000; 12:209-215.

13. Zheng J, Ramirez VD. Inhibition of mitochondrial proton F0F1-ATPase/ATP synthase bypolyphenolic phytochemicals Br J Pharm 2000; 130:1115-1123.

14. Yoon HS, Moon SC, Kim ND, Park BS, Jeong MH, Yoo YH. Genistein induces apoptosis of RPE-J cells by opening mitochondrial PTP. Biochem Biophys Res Commun 2000; 276:151156.

15. Salvi M, Brunati AM, Clari G, Toninello A. Interaction of genistein with the mitochondrial electron transport chain results in opening of the membrane transition pore. Biochim Biophys Acta 2002; 1556:187-196.

16. Martin KR. Targeting apoptosis with dietary bioactive agents. Exp Biol Med (Maywood) 2006; 231:117-129.

17. Khan N, Afaq F, Mukhtar H. Apoptosis by dietary factors: the suicide solution for delaying cancer growth. Carcinogenesis 2007; 28:233-239.

18. Zeng H, Chen Q, Zhao B. Genistein ameliorates beta-amyloid peptide (25-35)-induced hippocampal neuronal apoptosis. Free Radic Biol Med 2004; 36:180-188.

19. Akiyama T, Ishida J, Nakagawa S, Ogawara H, Watanabe S, Itoch N, Shibuya M, Fukami Y. Genistein, a specific inhibitor of tyrosine-specific protein kinases. J Biol Chem 1987; 262: $5592-5595$.

20. Ohigashi T, Ueno M, Nonnnaka S, Nakanoma T, Furukawa Y, Deguchi N, Murai M. Tyrosin kinase inhibitors reduce bel-2 expression and induced apoptosis in androgen-depent cells. Am J Physiol 2000; 278:C66-C72.

21. Lin C-M, Chen C-S, Chen C-T, Liang Y-C, Lin J-K. Molecular modeling of flavonoids that inhibits xanthine oxidase. Biochem Biophys Res Commun 2002; 294:167-172.

22. Das A, Banik NL, Ray SK Mechanism of apoptosis with the involvement of calpain and caspase cascades in human malignant neuroblastoma SH-SY5Y cells exposed to flavonoids. Int J Cancer 2006; 119:2575-2585.

23. Linford NJ, Dorsa DM. 17h-Estradiol and the phytoestrogen genistein attenuate neuronal apoptosis induced by the endoplasmic reticulum calcium-ATP inhibitor thapsigargin.

Steroids 2002; 67:1029-1040. 
24. Hee K, Oh YB, Min WJ, Sang DH, Hyun SH, Kyoon H, Seung UK, Inhee MJ. Neuroprotective effects of estrogen against beta-amyloid toxicity are mediated by estrogen receptors in cultured neuronal cells. Neurosci Lett 2001; 302:58-62.

25. Shuba LM, Asai T, Pelzer S, McDonald TF. Activation of cardiac chloride conductance by the tyrosine kinase inhibitor, genistein. Br J Pharmacol 1996; 119:335-345.

26. Mao Z, Zheng YL, Zhang YQ, Han BP, Zhu XW, Chang Q, Hu XB. The anti-apoptosis effects of daidzein in the brain of D-galactose treated mice. Molecules 2007; 12:1455-1470.

27. Lai HH, Yen GC. Inhibitory effect of isoflavones on peroxynitrite-mediated low-density lipoprotein oxidation. Biosci Biotechnol Biochem 2002; 66:22-28.

28. Guo JM, Xiao BX, Liu DH, Grant M, Zhang S, Lai YF, Guo YB, Liu Q. Biphasic effect of daidzein on cell growth of human colon cancer cells. Food Chem Toxicol 2004; 42:16411646.

29. Klein CB, King AA. Genistein genotoxicity: critical considerations of in vitro exposure dose. Toxicol Appl Pharmacol 2007; 224:1-11.

30. Foti P, Erba D, Riso P, Spadafranca A, Criscuoli F, Testolin G. Comparison between daidzein and genistein antioxidant activity in primary and cancer lymphocytes. Arch Biochem Biophys 2005; 433:421-427.

31. King RA, Bursill DB. Plasma and urinary kinetics of the isoflavones daidzein and genistein after a single soy meal in humans. Am J Clin Nutr 1998; 67:867-872.

32. Sumbayev VV. Genistein effect on xanthine oxidase activity. Ukr Biokhim Zh 2001; 73:3943.

33. Lin CM, Chen CS, Chen CT, Liang YC, Lin JK. Molecular modeling of flavonoids that inhibits xanthine oxidase. Biochem Biophys Res Commun 2002; 294:167-172.

34. Levi G, Aloisi F, Ciotti MT, Gallo V. Autoradiographic localization and depolarization induced release of acidic amino acids in differentiating cerebellar granule cell cultures. Brain Res 1984; 290:77-86.

35. D'Mello SR, Galli C, Ciotti T, Calissano P. Induction of apoptosis in cerebellar granule neurons by low potassium: inhibition of death by insulin-like growth factor I and cAMP. Proc Natl Acad Sci USA 1993; 90:10989-10993.

36. Stefanis L., Troy C. M., Qi H. and Greene L. A. (1997) Inhibitors of trypsin-like serine proteases inhibit processing of the caspase Nedd-2 and protect PC12 cells and sympathetic neurons from death evoked by withdrawal of trophic support. J. Neurochem. 69, 1425-1423.

37. Stefanis L., Park D. S., Friedman W. J. and Greene L. A. (1999) Caspase-dependent and independent death of camptothecin-treated embryonic cortical neurons. J. Neurosci. 19, 6235-6247.

38. Soto A. M. and Sonnenschein C. (1985) The role of estrogen on the proliferation of human breast tumor cells (MCF-7). J. Steroid Biochem. 23, 87-94.

39. Volontè C, Ciotti MT, Battistini L. Development of a method for measuring cell number: application to CNS primary neuronal cultures. Cytometry 1994; 17:274-276.

40. Hockenbery D., Nunez G., Milliman C., Schreiber R.D. and Korsemeyer S.J. (1990) Bcl-2 is an inner mitochondrial membrane protein that blocks programmed cell death. Nature 348, 334-336.

41. Berry MN, Edwards AM, Barritt GJ. Assessment of integrity of isolated hepatocytes. In: Burdon RH, Van Knippenberg PH editors. Laboratory techniques in chemistry and molecular biology. Amsterdam-New York-Oxford: Elsevier, Sc. Publ; 1991; 21:83-98.

42. Sjodin RA. Measurement of $\mathrm{Na}^{+}-\mathrm{K}^{+}$pump in muscle. Methods Enzymol 1989; 173:695-714. 
43. Waddel WJ, Hill C. A simple ultraviolet spectrophotometer method for the determination of protein. J Lab Clin Med 1956; 48:311-314.

44. Atlante A, Gagliardi S, Minervini G M, Ciotti MT, Marra E, Calissano P. Glutamate neurotoxicity in rat cerebellar granule cells: a major role for xanthine oxidase in oxygen radical formation. J Neurochem 1997; 68:2038-2045.

45. Atlante A, Valenti D, Gagliardi S, Passarella S. A sensitive method to assay the xanthine oxidase activity in primary cultures of cerebellar granule cells. Brain Res Brain Res Protoc 2000; 6:1-5.

46. Atlante A, Calissano P, Bobba A, Azzariti A, Marra E, Passarella S. Cytochrome $c$ is released from mitochondria in a reactive oxygen species (ROS)-dependent fashion and can operate as a ROS scavenger and as a respiratory substrate in cerebellar neurons undergoing excitotoxic death. J Biol Chem 2000; 275:37159-37166.

47. Bobba A, Atlante A, Petragallo VA, Marra E. Different sources of reactive oxygen species contribute to low potassium-induced apoptosis in cerebellar granule cells. Int J Mol Med 2008; 21:737-745.

48. Bobba A, Atlante A, Moro L, Calissano P, Marra E. Nitric oxide has dual opposite roles during early and late phases of apoptosis in cerebellar granule neurons. Apoptosis 2007; 12:1597-1610.

49. Bobba A, Atlante A, de Bari L, Passarella S, Marra E. Apoptosis and cytochrome $c$ release in cerebellar granule cells. In Vivo 2004; 18:335-344.

50. Atlante A, de Bari L, Bobba A, Marra E, Calissano P, Passarella S. Cytochrome $c$, released from cerebellar granule cells undergoing apoptosis or excytotoxic death, can generate protonmotive force and drive ATP synthesis in isolated mitochondria. J Neurochem 2003; 86:591-604.

51. Kristal BS, Brown AM. Apoptogenic ganglioside GD3 directly induces the mitochondrial permeability transition. J Biol Chem 1999; 274:23169-23175.

52. Basso E, Fante L, Fowlkes J, Petronilli V, Forte MA, Bernardi P. Properties of the permeability transition pore in mitochondria devoid of Cyclophilin D. J Biol Chem 2005; 280:18558-18561.

53. Valencia A, Moran J. Reactive oxygen species induce different cell death mechanisms in cultured neurons Free Rad Biol Med 2004; 36:1112-1125.

54. Mercer LD, Kelly BL, Horne MK, Beart PM. Dietary polyphenols protect dopamine neurons from oxidative insults and apoptosis: investigations in primary rat mesencephalic cultures. Biochem Pharmacol 2005; 69: 339-345.

55. Szkudelska K, Nogowski L. Genistein - a dietary compound inducing hormonal and metabolic changes. J Steroid Biochem Mol Biol 2007; 105:37-45.

56. Takahashi Y, Odbayar TO, Ide T. A Comparative Analysis of Genistein and Daidzein in Affecting Lipid Metabolism in Rat Liver. J Clin Biochem Nutr 2009; 44:223-230.

57. Cai Q, Wei H. Effect of dietary genistein on antioxidant enzyme activities in SENCAR mice. Nutr Cancer 1996; 25:1-7.

58. Choi EJ. The prooxidant, rather than antioxidant, acts of daidzein in vivo and in vitro: daidzein suppresses glutathione metabolism. Eur J Pharmacol 2006; 542:162-169.

59. Wijeratne SS, Cuppett SL. Soy isoflavones protect the intestine from lipid hydroperoxide mediated oxidative damage. J Agric Food Chem 2007; 55:9811-9816.

60. Paul MK, Mukhopadhyay AK. Tyrosine kinase - Role and significance in Cancer. Int J Med Sci 2004;1:101-115. 
61. Sarkar FH, Li Y. Mechanisms of cancer chemoprevention by soy isoflavone genistein. Cancer and Metastasis Reviews 2002; 21:265-280.

62. Shi C, Xu J. Increased vulnerability of brain to estrogen withdrawal-induced mitochondrial dysfunction with aging. J Bioenerg Biomembr 2008; 40:625-630.

63. Santos AC, Uyemura SA, Lopes JL, Bazon JN, Mingatto FE, Curti C. Effect of naturally occurring flavonoids on lipid peroxidation and membrane permeability transition in mitochondria. Free Radic Biol Med 1998; 24:1455-1461. 

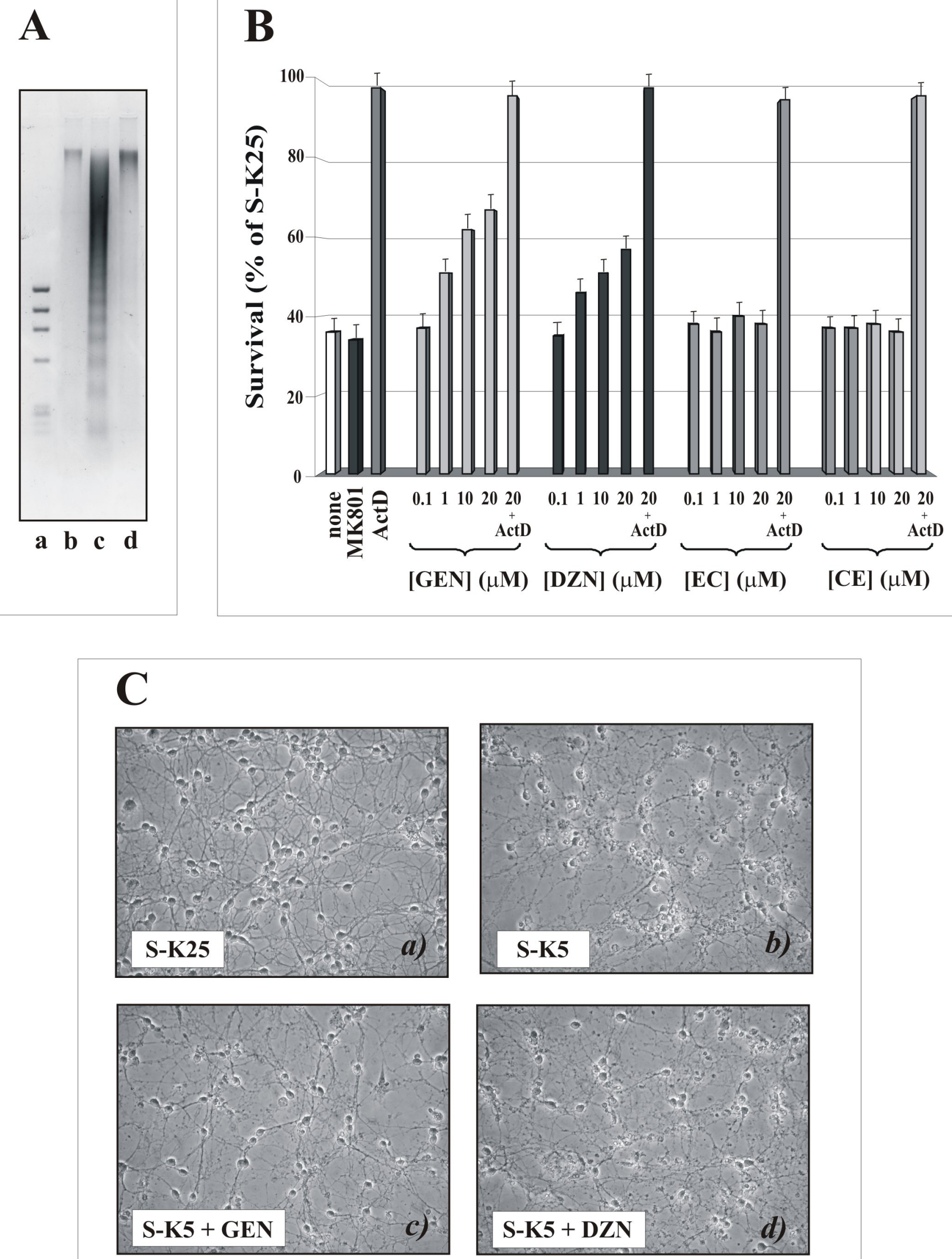


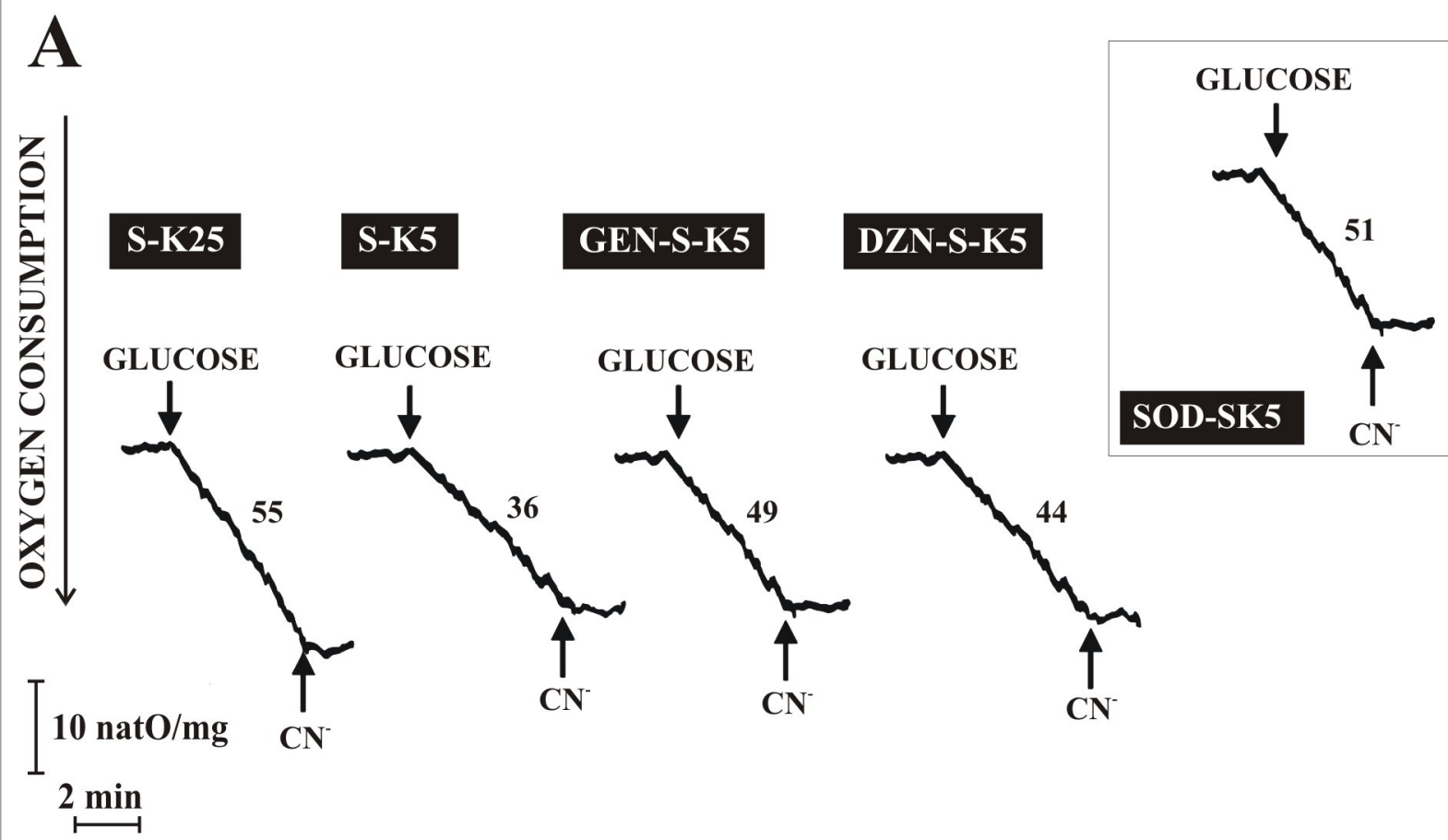

B GEN and DZN prevent the impairment of cellular respiration by glucose in cells undergoing apoptosis.

\begin{tabular}{|c|c|}
\hline Treatment & $\mid \begin{array}{c}\mathbf{V}_{\mathrm{O}_{2}}(\text { glucose }) \pm \text { s.d. } \\
\text { (Natomo/min x mg cell protein })\end{array}$ \\
\hline S-K25 & $55 \pm 5$ \\
\hline S-K5 & $36 \pm 4$ \\
\hline $\mathrm{S}-\mathrm{K} 5+\mathrm{GEN} 0.1 \mu \mathrm{M}$ & $37 \pm 3$ \\
\hline S-K5 + GEN $1 \mu \mathrm{M}$ & $39 \pm 3$ \\
\hline S-K5 + GEN $10 \mu \mathrm{M}$ & $45 \pm 4(* *)$ \\
\hline S-K5 + GEN $20 \mu \mathrm{M}$ & $49 \pm 4\left(^{* \star}\right)$ \\
\hline $\mathrm{S}-\mathrm{K} 5+\mathrm{DZN} 0.1 \mu \mathrm{M}$ & $35 \pm 4$ \\
\hline $\mathrm{S}-\mathrm{K} 5+\mathrm{D} Z \overline{Z N} 1 \mu \mathrm{M}$ & $37 \pm 3$ \\
\hline $\mathrm{S}-\mathrm{K} 5+\mathrm{DZN} 10 \mu \mathrm{M}$ & $40 \pm 3(*)$ \\
\hline S-K5 + DZN $20 \mu \mathrm{M}$ & $44 \pm 4(* *)$ \\
\hline
\end{tabular}




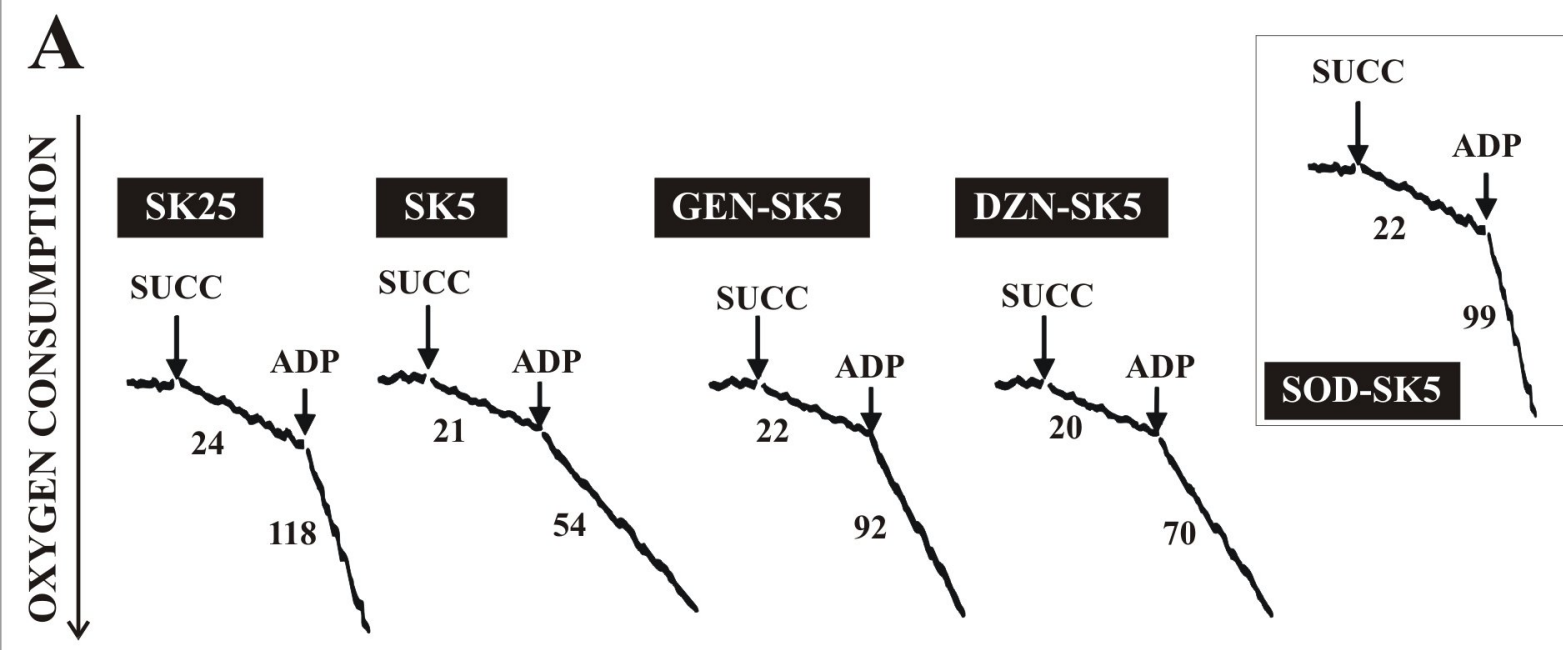

$\left[\begin{array}{l}10 \text { natO/mg } \\ 2 \text { min }\end{array}\right.$

B

GEN and DZN prevent the decrease of RCR by succinate plus ADP in cells undergoing apoptosis.

\begin{tabular}{|c|l|}
\hline Treatment & RCR \\
& \\
\hline SK25 & $5.0 \pm 0.4$ \\
\hline SK5 & $2.7 \pm 0.3$ \\
\hline SK5 + GEN 0.1 $\mu \mathrm{M}$ & $2.6 \pm 0.3$ \\
\hline SK5 + GEN 1 $\mu \mathrm{M}$ & $2.9 \pm 0.3\left(^{* *}\right.$ \\
\hline SK5 + GEN $10 \mu \mathrm{M}$ & $3.4 \pm 0.3\left(^{* *}\right)$ \\
\hline SK5 + GEN $20 \mu \mathrm{M}$ & $4.2 \pm 0.5\left(^{* * *}\right)$ \\
\hline SK5 + DZN $0.1 \mu \mathrm{M}$ & $2.7 \pm 0.4$ \\
\hline SK5 + DZN $1 \mu \mathrm{M}$ & $2.6 \pm 0.4$ \\
\hline SK5 + DZN $10 \mu \mathrm{M}$ & $3.0 \pm 0.3(*)$ \\
\hline SK5 + DZN $20 \mu \mathrm{M}$ & $3.5 \pm 0.4\left(^{* *}\right)$ \\
\hline
\end{tabular}


$\mathbf{A}$

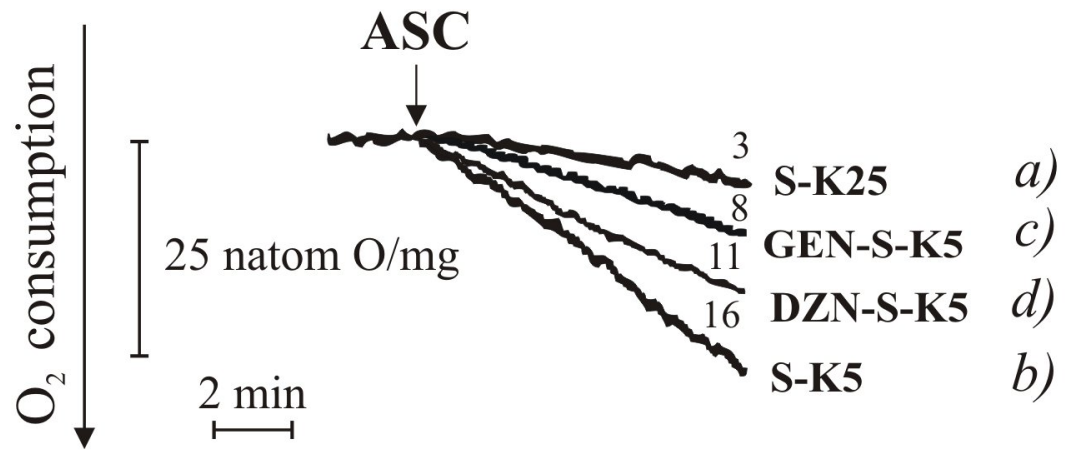

B

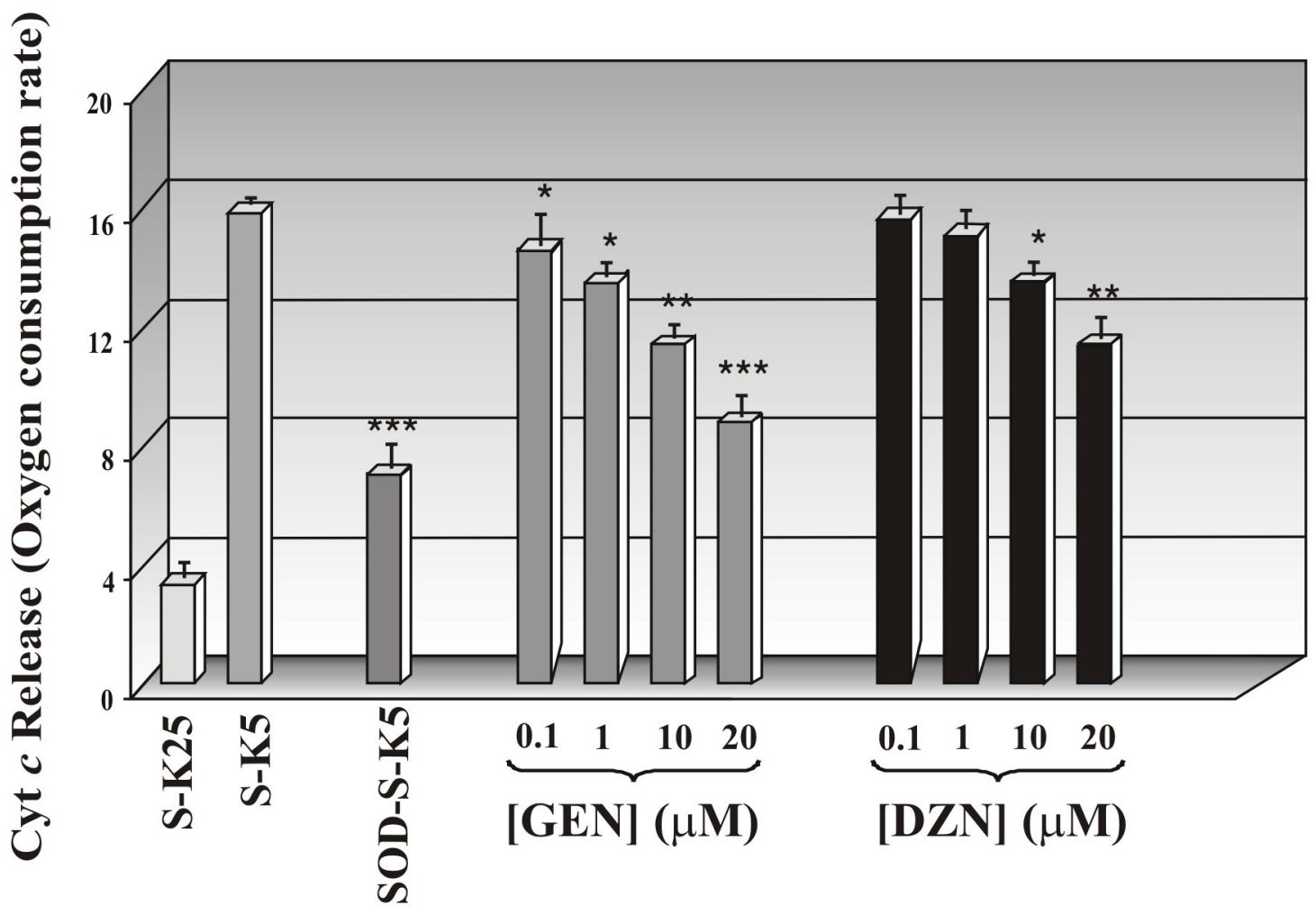

Fig. 4 

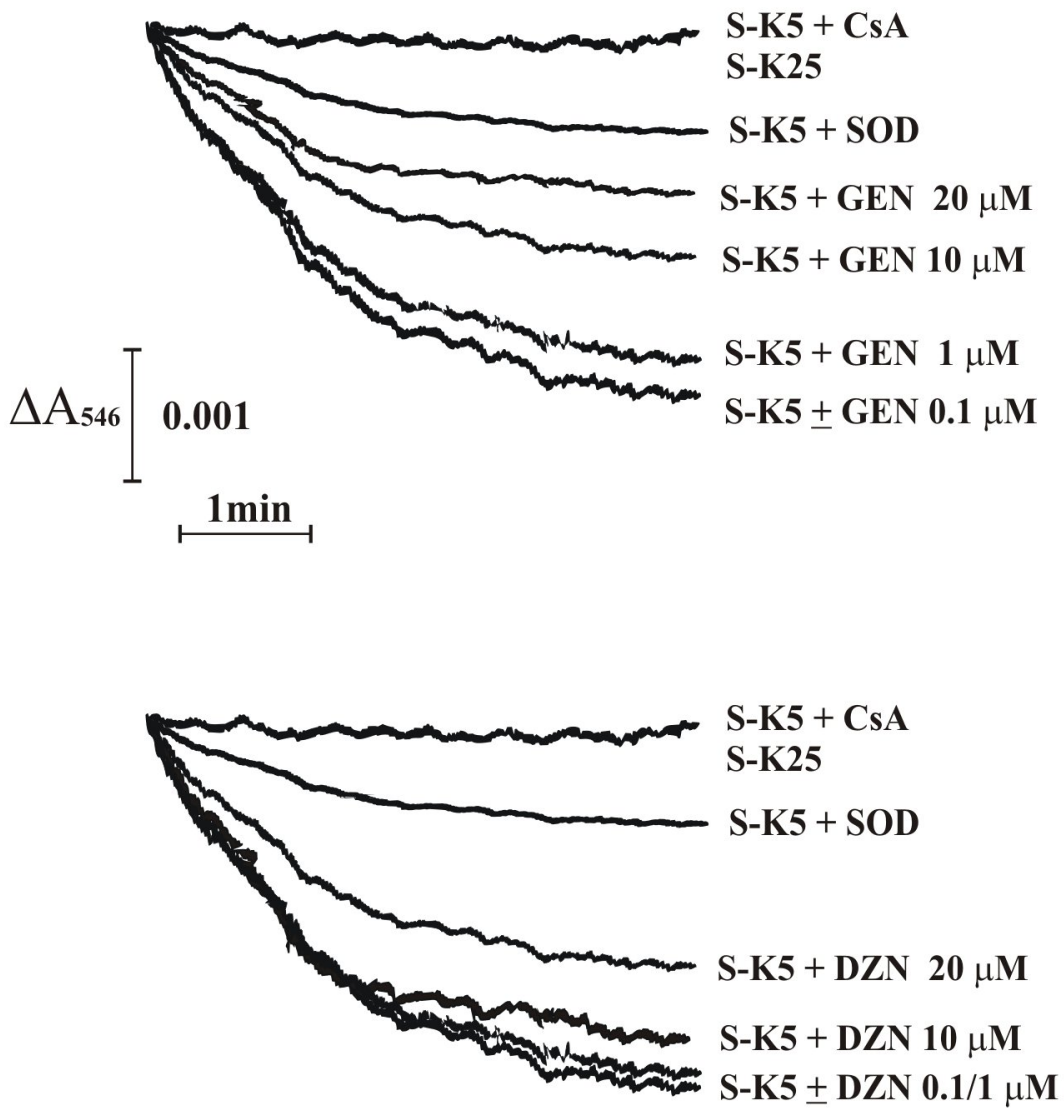


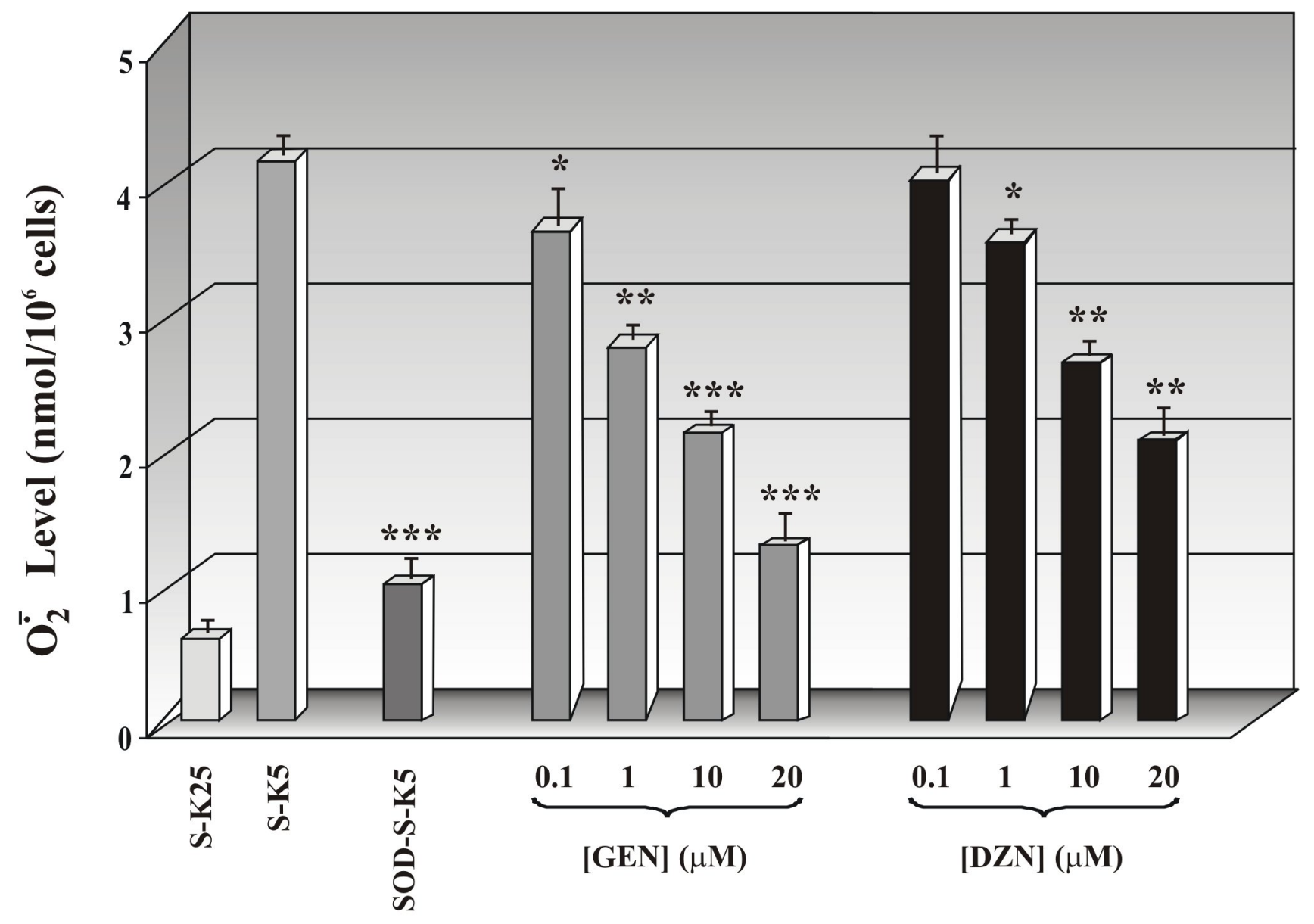

Fig. 7 


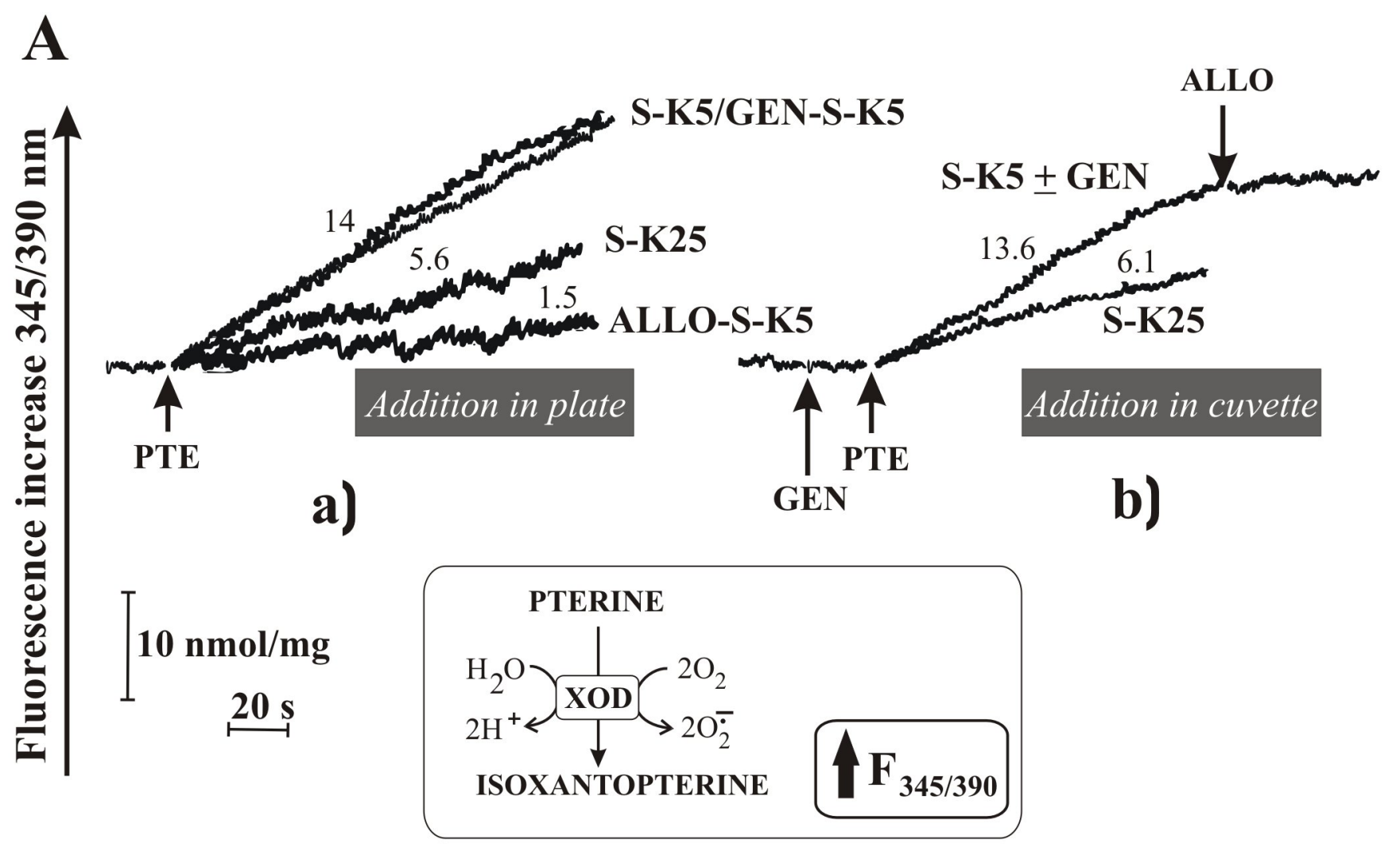

B
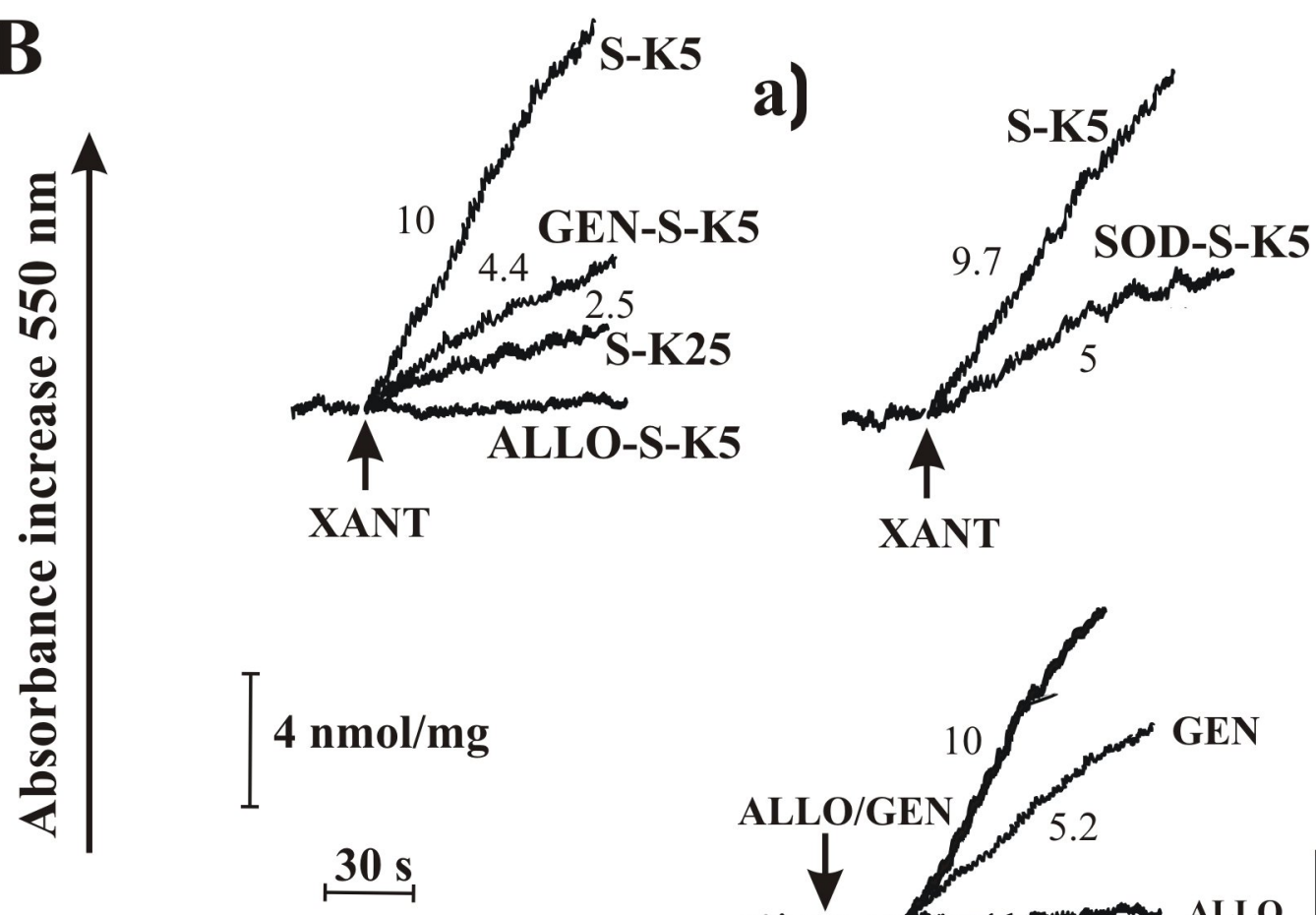

b)

Addition in plate

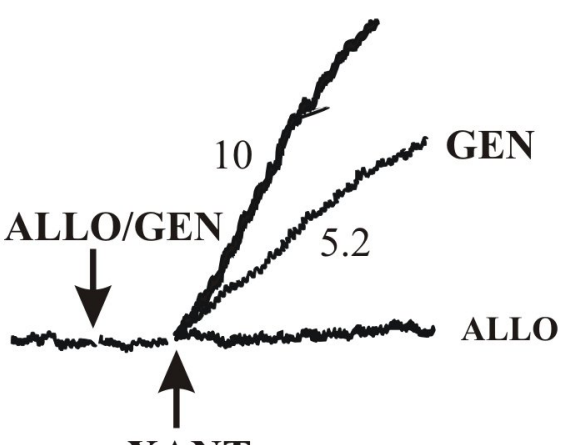

c)

Addition in cuvette

XANT

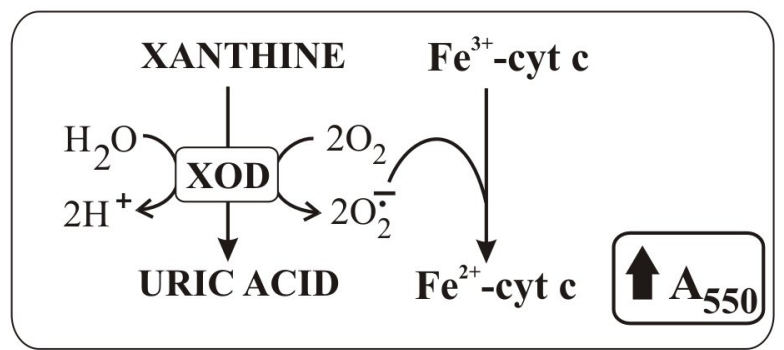

Fig. 8 

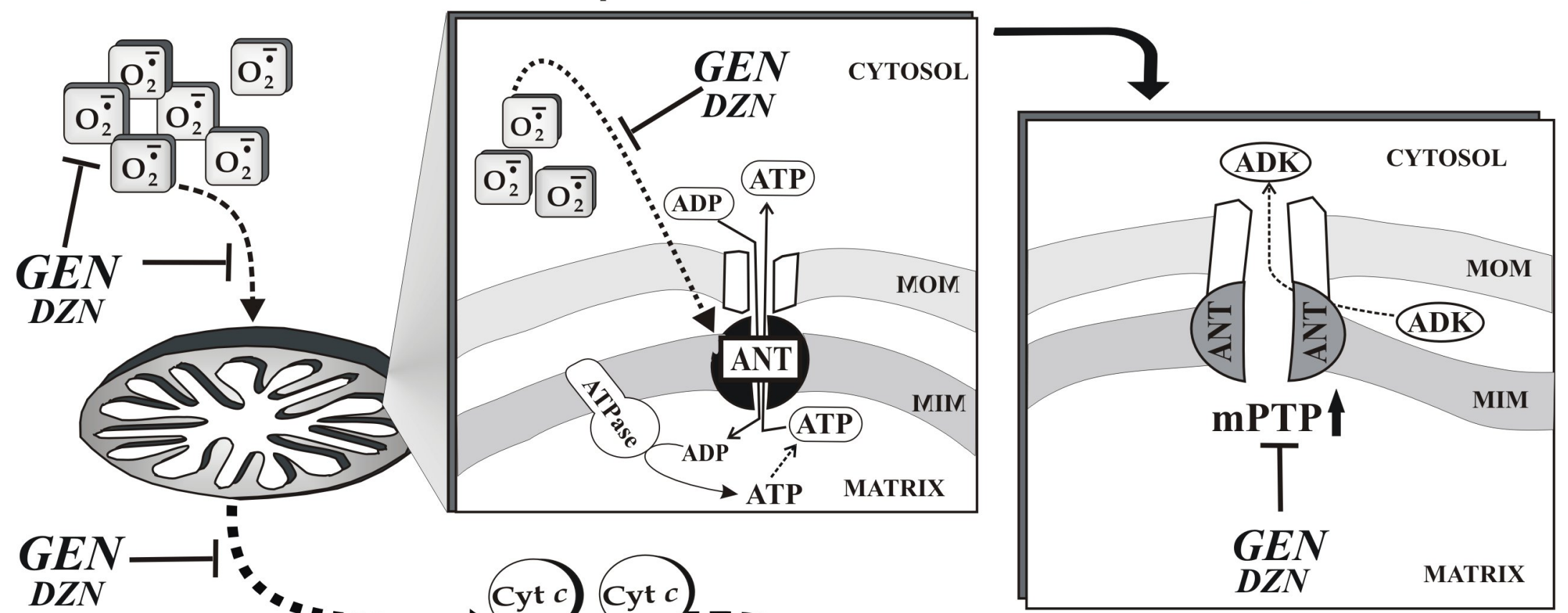

GEN $\underset{D Z N}{G E N}$

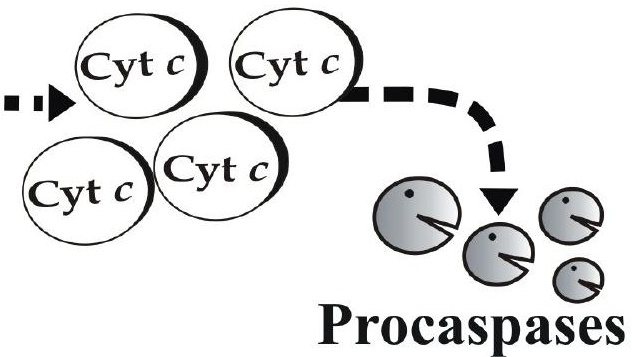
$D Z N$

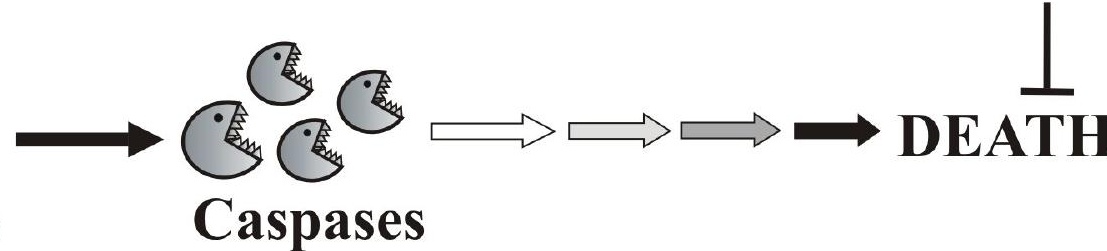

